\title{
Carbon Nanotube Films for Energy Applications
}

\author{
Monika Rdest ${ }^{1}$ and Dawid Janas ${ }^{2, *}$ (]) \\ 1 Department of Materials Science and Metallurgy, University of Cambridge, 27 Charles Babbage Rd, \\ Cambridge CB3 0FS, UK; Monika.Rdest@gmail.com \\ 2 Department of Organic Chemistry, Bioorganic Chemistry and Biotechnology, \\ Silesian University of Technology, B. Krzywoustego 4, 44-100 Gliwice, Poland \\ * Correspondence: Dawid.Janas@polsl.pl; Tel.: +48-32-237-10-82
}

check for

updates

Citation: Rdest, M.; Janas, D. Carbon

Nanotube Films for Energy

Applications. Energies 2021, 14, 1890.

https://doi.org/10.3390/en14071890

Academic Editors:

Carlos Miguel Costa

and Dmitri A. Bulushev

Received: 1 March 2021

Accepted: 27 March 2021

Published: 29 March 2021

Publisher's Note: MDPI stays neutral with regard to jurisdictional claims in published maps and institutional affiliations.

Copyright: (c) 2021 by the authors. Licensee MDPI, Basel, Switzerland. This article is an open access article distributed under the terms and conditions of the Creative Commons Attribution (CC BY) license (https:/ / creativecommons.org/licenses/by/ $4.0 /)$.

\begin{abstract}
This perspective article describes the application opportunities of carbon nanotube (CNT) films for the energy sector. Up to date progress in this regard is illustrated with representative examples of a wide range of energy management and transformation studies employing CNT ensembles. Firstly, this paper features an overview of how such macroscopic networks from nanocarbon can be produced. Then, the capabilities for their application in specific energy-related scenarios are described. Among the highlighted cases are conductive coatings, charge storage devices, thermal interface materials, and actuators. The selected examples demonstrate how electrical, thermal, radiant, and mechanical energy can be converted from one form to another using such formulations based on CNTs. The article is concluded with a future outlook, which anticipates the next steps which the research community will take to bring these concepts closer to implementation.
\end{abstract}

Keywords: carbon nanotubes; thin films; energy applications

\section{Introduction}

The global energy demand continues to rise at a staggering rate. Ritchie and Roser showed that in the last 100 years, world energy consumption increased from ca. 18,000 TWh in the 1920s to ca. 160,000 TWh in 2018 [1]. Change by orders of magnitude was deemed necessary to support the development of civilization, in which energy is now utilized in many ways. It is evident that the times when energy was mainly used only for heating, cooking, or simple processing are long gone. At present, much more advanced applications are the reality. We manage various forms of energy in our daily life without even noticing. A simple smartphone or computer, on which you are reading this paper, is a multifunctional tool that transforms various forms of energy in the background to enable the device to serve its purpose.

Various materials can be used to mediate the conversion of one form of energy into the other. The discovery of nanomaterials revealed that they can be handy for this purpose due to their unique properties as they are constrained to 0D, 1D, or 2D architectures [2-5]. Specifically, carbon nanomaterials, such as carbon nanotubes (CNTs) or graphene, have shown a remarkable performance on this front ever since these materials were made famous at the turn of the XX and XXI century [6,7]. Properties such as ballistic conduction [8], remarkable thermal conductivity [9], or unparalleled strength [10] have attracted a significant share of the scientific community, which in turn has laid the foundation for the development of a wide range of applications. Most of the applications relevant to these properties require the material to take the form of macroscopic networks, such as films [11] or fibers [12], to exploit the merits of the material on a real-life scale. Over the years, many techniques have been devised for how such networks can be manufactured. These ensembles are lightweight [13,14], flexible [15], resistant to extreme operational conditions [16,17], and can be produced from sustainable sources [18], which is essential from the environmental point of view. Interestingly, the characterization of carbon nanomaterials has demonstrated that 
they have enormous utility potential in energy conversion and storage [19-21] applications, especially when used in the form of the aforementioned networks.

In this perspective article, the most promising exploitation areas for macroscopic CNT films for energy management are showcased. The report begins with a description of the mainstream methods used to produce such macrostructures. A range of applications concerning electrical, thermal, radiant, and mechanical energy are presented. The contribution is concluded with a summary of the main findings enclosed herein. Finally, future perspectives for the utilization of CNTs in these scenarios are also provided to indicate gaps in knowledge which should be solved. Exploring these new research directions should provide a more thorough understanding of the nature of nanocarbon, which eventually should bring it closer to the appropriate technology readiness level necessary for implementation. Transparent coatings are not considered extensively in this article, so readers are advised to seek information regarding this topic in other dedicated reviews [22,23].

\section{Synthesis of CNT Films}

There is an assortment of techniques for how one can obtain CNT films (Figure 1). These can be divided into liquid- and solid-based methods. In the first category, a liquid medium is required wherein CNTs are dispersed. Van der Waals forces between them are collectively strong, so some sort of agitation must be applied to overcome these interactions and cause individualization. Standard techniques to accomplish this goal involve either sonication [24] or shear mixing [25], which deliver sound and mechanical energy, respectively. Simultaneously, to improve the compatibility of CNTs with the solvent (particularly with water), oxidation of the material is conducted before the dispersion step [26,27]. This introduces appropriate functional groups, which increase the affinity of CNTs to the liquid medium. Since oxidation is most commonly disruptive in nature and deteriorates the properties of the material, another popular route is to focus on physical interactions. In such a case, surfactants are used to make CNTs compatible. Amphiphilic chemical compounds, such as sodium dodecyl sulfate [28], sodium dodecylbenzene sulfonate [29], cetyltrimethylammonium bromide [30], or Pluronic [31], can all be engaged for this purpose. Regardless of the surfactant type (anionic/cationic/non-ionic/amphoteric), these species improve the dispersibility of CNTs in liquid medium by mediating the interaction between the medium and the CNTs.

Once such CNT dispersion is obtained, it can be deposited onto a substrate in many ways. Among the simplest and oldest methods of CNT film formation is called dip coating (Figure 1a) [32-36]. In this approach, a substrate is immersed in a reservoir containing a CNT dispersion, and then the substrate is withdrawn for drying. With each immersion step, the CNT film's thickness grows in a decelerating fashion because some of the material re-disperses in the solvent. This is very well illustrated by the influence of the number of dips on the obtained CNT films' electrical properties. The first few deposition rounds strongly enhance the conductivity of the network, but after reaching a certain threshold, the improvement is less substantial [37]. For dip coating, it helps to use a highly volatile solvent, such as chlorinated hydrocarbons [38,39] or low-molecular-weight alcohols [40,41], to facilitate the evaporation, which in turn reduces the dead processing times between the dips. It has recently been shown that this simple technique can yield the excellent alignment of CNTs in the film [42]. To make this possible, CNTs were dispersed with poly[9-(1-octylonoyl)-9H-carbazole2,7-diyl] in toluene to identify those of semiconducting characteristics. The polymer was then removed by tetrahydrofuran, and CNTs were redispersed in 1,1,2-trichloroethane to increase the semiconducting purity. Afterward, the CNTs were again dispersed in toluene using the aforementioned polymer. After three rounds of such processing, the material contained $>99.9999 \%$ of semiconducting-type CNTs. 
(a)

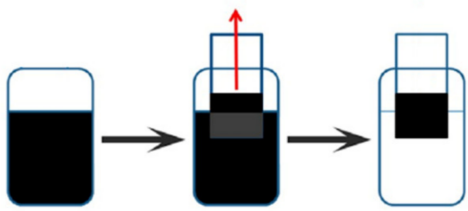

(c)

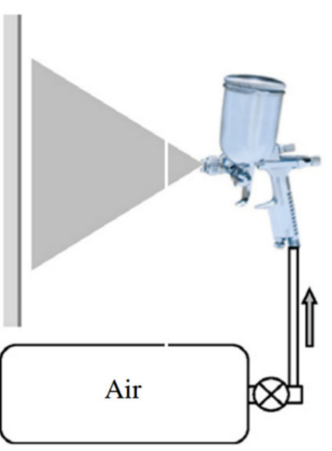

(e)

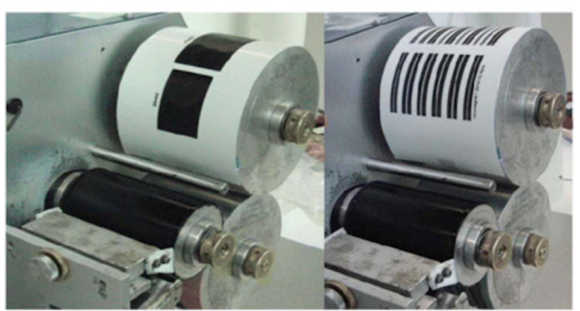

(b)

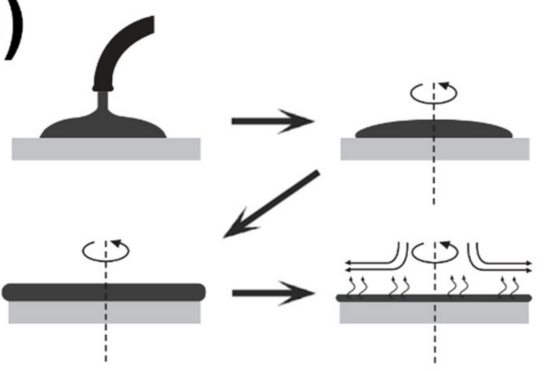

(d)

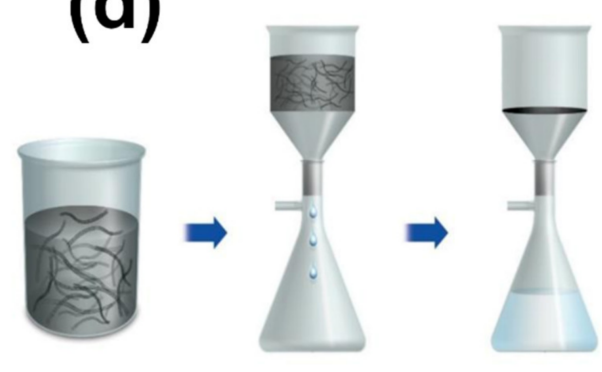

(f)

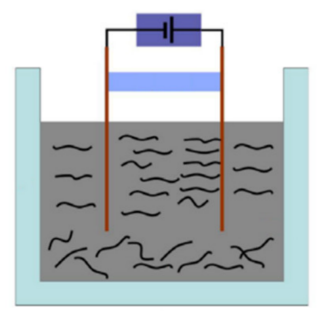

(h)

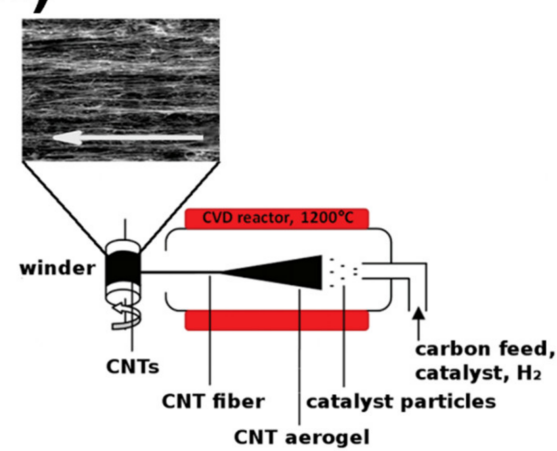

Figure 1. Overview of techniques of producing carbon nanotube (CNT) films. (a) Dip coating reproduced with permission from [32], copyright the American Chemical Society (2012); (b) spin coating reproduced with permission from [43], copyright Woodhead Publishing Ltd. (2013); (c) spray coating reproduced with permission from [44], copyright Elsevier Ltd. (2012); (d) filtration reproduced with permission from [45], copyright MDPI (2016); (e) printing reproduced with permission from [46], copyright SAGE Publications Ltd. (2011); (f) electrophoresis reproduced with permission from [47], copyright Elsevier Ltd. (2006); (g) array drawing reproduced with permission from [48], copyright IOP Publishing Ltd. (2009); and (h) direct spinning reproduced with permission from [49], copyright Royal Society of Chemistry (2016). 
An interesting concept was employed using the sorted material mentioned above to afford highly aligned CNTs by dip coating. The substrate was rinsed with 2-butene-1,4-diol, and then it was slowly immersed and withdrawn from the CNT dispersion. Hydrogen bonding between the polymer and 2-butene-1,4-diol resulted in an outstanding material alignment (Figure 2). Field-Effect Transistors fabricated from this source showed excellent performance surpassing that of silicon. Coming back to the main topic, the key drawback of dip coating is the lack of uniformity in the thickness of the CNT film. Due to gravity, the film is often thicker at the substrate end injected deeper into the CNT reservoir. To alleviate this problem, spin coating can be employed [50,51]. In this process, the spinning of the substrate evens out the thickness of the CNT film (Figure 1b). Unfortunately, because of that, the excess material is often wasted to reach homogeneity.

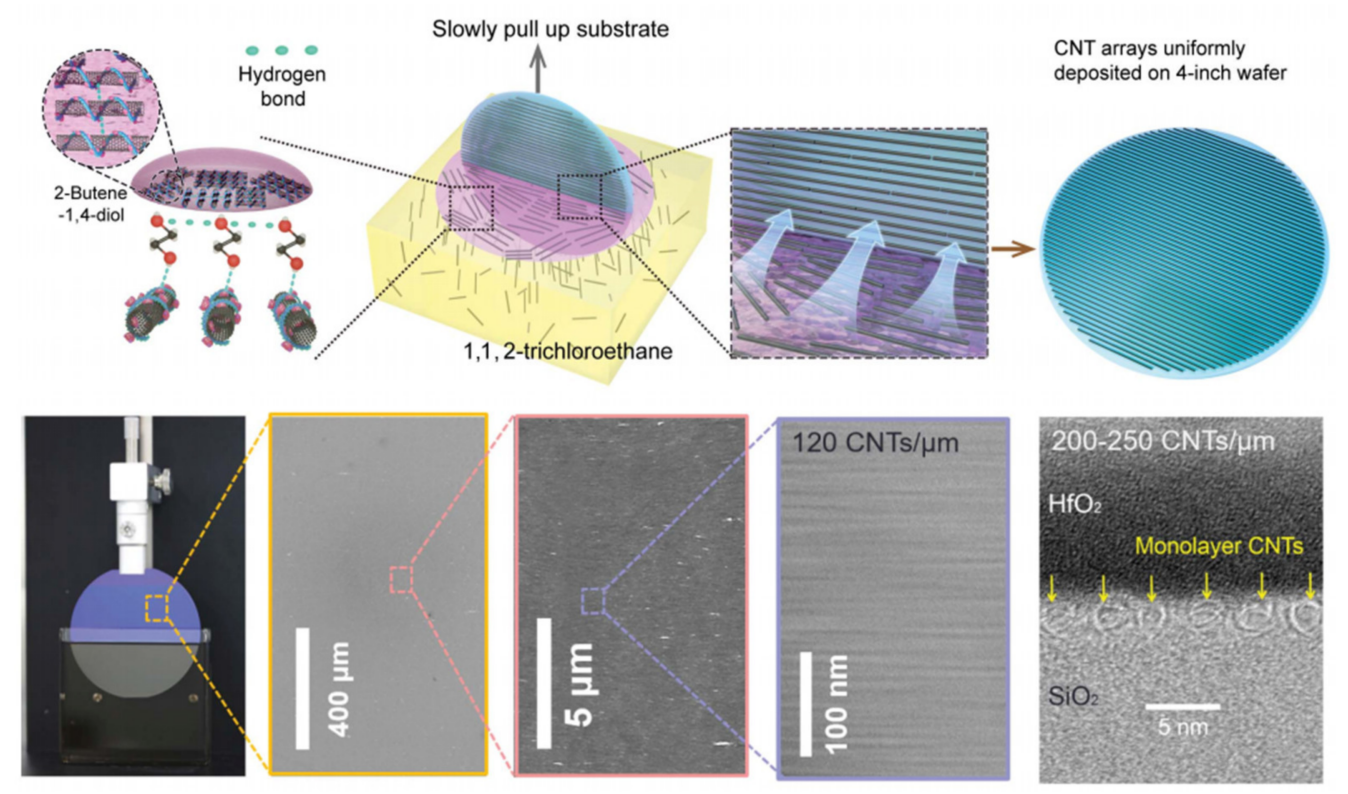

Figure 2. Alignment of CNT films produced by dip coating, reproduced with permission from [42]. Copyright the authors (2020).

Another way that the material can be made more uniform involves a CNT dispersion and compressed gas (Figure 1c) [52-55]. Combining these two creates a fine mist of CNTs, which readily deposits onto the substrate. Spray coating is very quick, and the time between the deposition of layers is considerably reduced compared with dip coating.

The concept, which is significantly different from already described methods, is based on filtration principles (Figure 1d) [56-60]. A CNT dispersion is passed through a membrane with appropriate porosity. The liquid medium permeates across the membrane, whereas the filter captures the CNT filter cake. The process is commonly facilitated by employing the pressure on the funnel or vacuum in the receiving flask. For this process, a filter type to which CNTs have low adhesion (e.g., produced from PTFE) is preferred to separate nanocarbon from the substrate after deposition. An alternative is to use a dissolvable membrane from mixed cellulose esters, which upon contact with an organic solvent readily disintegrates to liberate the CNT film $[57,60]$. Importantly, from the product point of view, it has recently been shown that this approach can also yield aligned CNT films when the process is conducted using diluted CNT dispersions over a prolonged time period [61]. In addition to the merits of this approach, one of the disadvantages is that as the film grows in thickness, the process greatly decelerates.

CNT film dispersions can also be printed through conventional inkjet technology (Figure 1e) $[46,62]$. This enables one to achieve a high level of detail as the printer head can make the films in complicated shapes on demand in a fully automated way. However, due to the unique structural characteristics of CNTs, which determine the fluid mechanics of 
the printed solution, it is often more challenging than expected. To ensure that the process proceeds uninterruptedly, the proper homogenization of CNTs is essential.

Lastly, it is also possible to create CNT films with electric current assistance by electrophoresis (Figure 1f) [47,63-66]. A conductive substrate is coated with CNTs when current is passed through their dispersion. The dispersed CNTs respond to the presence of an electric field mainly due to the presence of surfactant and coat the substrate. The process is conceptually simple but somewhat difficult to scale up when compared with the other methods.

CNT films can also be manufactured from solid substrates either by array drawing (Figure 1g) $[48,67,68]$ or by direct spinning (Figure 1h) $[49,69]$. In the former approach, a so-called forest made up of vertically aligned CNTs is carefully drawn in the perpendicular direction of the array alignment axis. The material reassembles into sheets due to strong van der Waals forces between the CNTs which keep them together. Due to this, some of the arrays cannot be spun. If the CNTs are located too sparsely, or the degree of alignment is inferior, then it is difficult or impossible to produce CNT films this way. On the other hand, the former technique, the direct spinning method, takes a different approach. It is the only method presented in this article, which combines the synthesis of CNTs with the manufacture of networks from them in a single step. CNTs are synthesized inside of a high-temperature reactor by Chemical Vapor Deposition (CVD), which produces an elastic aerogel therein. Once it is attached to a rotating bobbin outside the furnace, the material can be continuously collected as films after an appropriate reaction time. Compaction of the processing makes it simple, but a disadvantage is that relatively small amounts of material can be produced on a weight basis.

The following sections highlight promising applications of CNT films prepared by the methods outlined above. The list is by no means exhaustive, because the purpose of this contribution is to indicate vigorously explored research areas at present using this high-performance nanocarbon material.

\section{CNT Films for Energy Applications}

CNT ensembles are evaluated in several sectors, all of which involve either the generation, transformation, or utilization of electrical, thermal, radiant, and mechanical energy. They are described below in the order mentioned above.

\subsection{Electrical Energy}

The electrical applications of CNT films are the most explored, as perhaps their characterization is often the least challenging. Furthermore, the manufacture of a successful device opens a broad spectrum of possible implementations in microelectronics or power engineering. Three areas of the most intensive research focus were selected for analysis.

\subsubsection{Conductive Networks}

CNT films prepared by either one of the highlighted techniques are almost always electrically conductive. Depending on the type of CNTs used for their construction and impurity content, the material is appropriate for different fields of exploitation. For instance, the networks mainly made up of metallic CNTs can be utilized to manufacture highperformance conductors. In contrast, the materials rich in semiconducting CNTs are particularly useful for applications wherein the network requires sensorial capabilities [15]. Due to the presence of band gaps, such a device conducts current only upon reaching a specific voltage threshold, which can be more easily affected [70,71].

The electrical conductivity of neat CNT films, as a result, spans many orders of magnitude, and, according to recent reports, their capabilities already exceed 10,000 S/ cm [72]. Typically, to reach high performance, various measures must be exercised. The electrical conductivity of CNT ensembles is chiefly affected by the purity of constituting CNTs, their electrical conductivity, and the degree of densification. A library of methods was established to enhance the electrical properties of CNT films on all three of these fronts. In 
the first case, both physical and chemical techniques can be used to remove the residual catalyst from the synthesis stage [73] and improve the graphitization of the structure [74,75]. After such processing, the charge transport operates more facilely as the phenomenon of scattering is minimized. Secondly, selecting CNTs of appropriate electrical conductivity is also necessary to produce a network of proper properties. For that to happen, recently, several CNT sorting strategies have been developed [76,77]. Thirdly, CNT films are porous structures abundant in voids filled with air, which deteriorates their charge propagation capabilities due to contact resistance [78]. To alleviate this problem, various densification tactics have recently been devised [72,79-82]. As illustrated by Tran and co-workers [72], such processing can not only increase the electrical conductivity by up to six-fold but simultaneously preserve the excellent mechanical properties. Indeed, among the key merits of the CNT films is their high flexibility, which opens perspectives for their implementation in flexible electronics. Therefore, it is appreciable that the boost indicated above did not occur at the expense of this property.

It must be stressed that the application of doping agents can considerably improve the electrical properties of CNT films. CNTs can both accept and donate electrons depending on the dopant choice, which results in $\mathrm{n}$ - and p-doping, respectively. As electron-poor dopants, species such as acids $[83,84]$ or halogens $[85,86]$ are commonly employed. Alternatively, electron-rich chemical compounds containing alkali metals $[86,87]$ or nitrogen $[88,89]$ can be used. A myriad of studies show the beneficial effect of incorporating such dopants into CNT films to increase their value. The addition of the dopant may, for instance, lower the band gap for semiconducting CNTs, and increase the DOS near the Fermi level for metallic CNTs [70].

Furthermore, one must also keep in mind the two niches in which CNT films excel the most, to match them with the best possible exploitation area. First of all, these materials are lightweight, so they are most suited for implementation in fields wherein weight is important, such as aeronautics, aviation, or automotive industries. This is why, sometimes, the recorded value of conductivity is recalculated to specific electrical conductivity, which takes weight into consideration. This reveals that CNT ensembles are already competitive with typical conductors $[85,90]$. Second, nanocarbon's electrical capabilities are often the most appreciable when the maximum current density is investigated rather than conductivity [91-93]. As illustrated in Hong and Myung's pioneering work, individual metallic SWCNTs can carry current densities higher by a factor of $10^{3}$ than copper [94]. Park and colleagues gave further evidence to support this [95]. CNT films were found to be remarkably durable and able to withstand extreme conditions when operated at high current carrying capacities in a non-oxidizing environment. One must keep in mind that the triple point of carbon at atmospheric pressure is at $3630^{\circ} \mathrm{C}$ [96], while copper is already molten at $1085^{\circ} \mathrm{C}$ [97], which acts in favor of the CNTs.

\subsubsection{Electrodes for Electrochemistry}

Due to their porosity and high electrical conductivity, the CNT films displayed high application potential in electrochemistry as they can easily facilitate charge/mass transfer. There are several notable areas of interest, which have received a significant share of attention. Firstly, CNT films can be used to generate non-fossil fuel resources, which can be used to obtain electricity when required. To date, perhaps the most work has been devoted to the generation of hydrogen as an energy vector. Water splitting can be conducted to produce hydrogen for this purpose, which CNT films can facilitate upon decoration with appropriate metal particles [98-100]. To improve the CNT network's electrical characteristics, graphene and its derivatives are also commonly incorporated [101,102]. Such solutions based on CNT ensembles have been proven to operate with high Hydrogen Evolution Reaction (HER) performance both in alkaline and acidic conditions. Although it has been reported that the CNT film by itself could catalyze the Hydrogen Evolution Reaction (HER) [103], one must keep in mind that they contain residual metallic catalyst nanoparticles from the synthesis stage, which are also catalytically active. Wang and 
Pumera made an insightful contribution regarding this issue [104]. In their paper, they indicated that residual metallic impurities may actually be present in many studies claiming the use of metal-free nanocarbon for catalysis. It was shown that many commonly used methods for material characterization, such as X-ray Photoelectron Spectroscopy (XPS), are not sensitive enough to validate such a claim. For instance, XPS is unable to detect metal content below $0.1 \mathrm{wt} \%$ [105]. Employing typical purification strategies is almost never fully successful [106-109], and even a seemingly negligible amount of metal may often provide most or all of the catalytic capabilities of such a system. The authors rightfully suggest the use of Inductively Coupled Plasma Mass Spectrometry/Optical Emission Spectrometry (ICP-MS/OES), Neutron Activation analysis, or X-ray Fluorescence to make a more accurate determination of the amount of residual metallic catalyst in unfunctionalized carbon nanostructures.

Alternatively, CNTs can also be used for Oxygen Reduction Reaction (ORR) to obtain a clean oxidant. Deng and colleagues showed how Fe-encapsulated pod-like CNTs facilitated such transformation [110]. It is important to mention that in such a configuration, metal nanoparticles are protected from the environment by CNT shells, thereby extending the life of the catalytic system. To enhance the performance of such a system, CNTs can be doped with nitrogen, which increases the DOS near the Fermi level and minimizes the local work function. Vazquez-Arenas et al. investigated the mechanism of ORR using $\mathrm{N}$-doped CNTs and found it to be similar to the typical Pt/C catalytic system [111]. Interestingly, acid-treated CNTs also exhibited a notable performance in ORR even when no metal nanoparticles were added [112]. This outcome was explained by (a) the favorable characteristics of the surface, which was hydrophilic upon the addition of $-\mathrm{OH},-\mathrm{COOH}$, and $\mathrm{C}=\mathrm{O}$ groups; $(\mathrm{b})$ the increased number of defect sites where the reaction takes place; and (c) doping modifying the charge distribution. Lee and colleagues published a comprehensive review on how the embedding of nitrogen and other components, such as polymers, transition metals, metal oxides/nitrides/sulfides, or quantum dots, into CNTs or graphene makes these materials appropriate for catalytic applications [113].

Furthermore, CNT films can also be used for the direct generation of electrical energy. For that to happen, they are used as components of Direct Fuel Cells (DFCs), which commonly exploit methanol as the fuel [114-117]. In such a case, they are referred to as Direct Methanol Fuel Cells (DMFCs). The predominant configurations exploit Pt-decorated CNT films, which are typically enhanced by alloying $\mathrm{Pt}$ with metals such as $\mathrm{Ru}, \mathrm{Rh}, \mathrm{Pd}$, $\mathrm{Au}, \mathrm{Cu}, \mathrm{Ni}, \mathrm{Co}, \mathrm{Fe}$, or Sn. By amalgamating these metals with Pt, the efficiency of methanol oxidation to carbon dioxide increases [114]. Such a bimetallic system outperforms simple $\mathrm{Pt} / \mathrm{CNT}$ electrocatalyst by more than $60 \%$. In addition to this gain, one must keep in mind that pure $\mathrm{Pt}$ is prone to poisoning by intermediates, such as $\mathrm{CO}$, and its use comes at a significant price burden, so combining $\mathrm{Pt}$ with other elements can alleviate these issues. Regarding the CNT film, its use as a support provides a large surface area. Hence, the metal can be deposited onto them in the form of nanoparticles. Additionally, the high electrical conductivity of the CNT network guarantees excellent charge mobility in the device, which justifies its high performance. Therefore, CNTs enable facile mass/charge transport, thereby enhancing the performance of DMFCs catalyzed by metal particles.

Similarly encouraging performance was obtained when vertically aligned N-doped $\mathrm{CNT}$ arrays were used as catalysts for flexible $\mathrm{Li}-\mathrm{CO}_{2}$ batteries [118]. A plethora of catalytic sites positioned along open mass-charge transfer channels afforded excellent rate capability and specific full discharge capacity when cycled more than a thousand times over a hundred days. Instead of N-doping, CNTs can also be decorated with nanoparticles from $\mathrm{Pt}$ [119], $\mathrm{Cu}$ [120], $\mathrm{Cu}_{x} \mathrm{Zn}_{1-\mathrm{x}} \mathrm{O}$ [121], or coated with cobalt phthalocyanine [122] to offer appreciable performance towards the electrochemical reduction of $\mathrm{CO}_{2}$, thereby tackling one of the great challenges of recent years.

Lastly, the electrochemical characteristics of CNT films make them a promising material for electrostimulation [123-127]. Electrical stimulation has been exploited for a long time to promote the treatment of many disorders. Various tissue types have been targeted 
by using such nanocarbon ensembles. For instance, Krukiewicz and co-workers showed that neat $\mathrm{CNT}$ films exhibited a promising performance in their implementation as flexible neural interfaces [123]. High cytocompatibility and appreciable mechanical properties were highlighted as the merits of such a solution. Notably, upon comparison against an electrode from $\mathrm{Pt}$, the application of $\mathrm{CNT}$ films proved beneficial, as their electrochemical parameters exceeded those of the reference material. The CNT film electrodes demonstrated a small impedance profile even at low frequencies $(>1 \mathrm{~Hz})$-almost two orders of magnitude lower than for the Pt control electrode. Neuronal signals have a small amplitude, so it is crucial to develop an interface which would be able to mimic such characteristics. Due to these features, CNT films have been proven to be useful for the treatment of various neurodegenerative diseases. Different tissues have been subjected to electrostimulation by using analogous formulations as well. Gerwig and colleagues illustrated how CNT films upon combination with poly(3,4-ethylenedioxythiophene) (PEDOT) can be used for the recording of signals and electrostimulation of a heart muscle [124]. The presented solution was found to be helpful for the analysis of cardiac and neurophysiological conditions. Moreover, electrodes from CNT films were found to promote the remodeling of the inner retina, with the aim to restore a degree of vision $[126,127]$. Electrophysiological recordings demonstrated a gradual decrease in stimulation thresholds and an increase in cellular recruitment. Successful results of these studies validate the concept of the application of CNT electrodes as neural prosthetic devices. Finally, CNT film electrodes can also facilitate bone cell proliferation, demonstrating their utility for bone regenerative medicine [125]. A composite of CNTs, glass, and hydroxyapatite exhibited a highly improved cell functional ability when proper electrostimulation was engaged. It is clear that such materials open new perspectives for regenerative medicine.

\subsubsection{Charge Storage}

The auspicious electrical properties of CNTs can also be exploited to store electrical charge due to their high electrical conductivity, durability, and chemical stability. There are two main options for the use of such nanocarbon networks for this purpose. Electrodes composed from them can either be used in batteries [103,128-134] or supercapacitors [135-138].

In the former case, CNT films are engaged as a support and current collector. Cui and colleagues showed how a Si-CNT nanocomposite afforded high specific charge storage capacity while simultaneously ensuring that $\mathrm{Li}$ insertion would not deteriorate the performance excessively [103]. The si-CNT film had a ten-fold higher specific capacity as compared with graphite/copper electrodes. Furthermore, the utilization of CNT films improves flexibility, electrical conductivity, and the chemical stability of Li-S batteries, as reported by Wei and co-workers [128]. The inclusion of CNTs makes the device much more flexible and less prone to cracking owing to considerable volume changes during discharge/recharge cycles upon Li (de)alloying [132]. Such electrodes based on CNTs can even be stretchable once a certain amount of polydimethylsiloxane (PDMS) is introduced [139]. CNTs are capable of experiencing considerable tension before fracture, which makes them an ideal material for this application. All these studies validate that CNT films have high application potential in the established Li-ion technology.

For some fields of exploitation, wherein the delivery of high current density is required over a short period of time, one must employ the so-called supercapacitors. CNTs have also been found to be a particularly suitable material for such a case $[135,137]$ due to their high capacitance and the mesoporous characteristics of the CNT films formed from them, the combined effect of which produces effective charge/mass transport [140]. In recent years, researchers have begun to combine the merits of graphene and CNTs $[134,136,141]$. A synergy is formed wherein the CNT films serve as a durable current collector of appropriate microstructures, whereas the graphene counterpart deposited on the CNTs offers high charge mobility. Notarianni demonstrated that such a composite structure already matches the performance of gold when considered as a current collector [141]. Similarly, other 2D nanostructures, such as transition metal dichalcogenides (TMDCs), are nowadays 
considered as an attractive component to be interfaced with CNT films. Such a hierarchical structure can, for instance, widen the operational conditions of the device when an asymmetric supercapacitor is constructed using CNT scaffolding and TMDCs [142-145]. For example, when $\mathrm{MoS}_{2}$ and $\mathrm{MnO}_{2}$ were deposited onto CNT films, excellent ohmic connection was established, and the amount of (de)intercalation sites was greatly increased, leading to the superior supercapacitive performance of the respective electrodes [146].

\subsection{Thermal Energy}

Films composed of CNTs are successfully employed for a spectrum of applications, wherein thermal energy is either transferred, utilized, or generated. In this section, the merits of their application for heat dissipation, utilization, or generation are shown.

\subsubsection{Heat Dissipation}

The high thermal conductivity of individual CNTs makes them ideal components for heat dissipation purposes [9]. Consequently, various networks based on CNTs have been created and utilized as so-called thermal interface materials (TIMs). Figure 3 demonstrates this concept. A vertically aligned CNT array of a thermal conductivity $\mathrm{k}_{\mathrm{CNT}}$ delivers heat from the hot side to the heat sink in the presented case. Thermal contact resistance Rc experienced at the CNT-heat sink interface limits the performance of the CNTs for this purpose. This constraint generally prevails over the bulk thermal resistance of the system [147]. Additionally, impurities, such as carbonaceous by-products arising from the synthesis, with low thermal conductivity, negatively impact CNT capabilities. These findings once again demonstrate that purification of the material before characterization is essential.

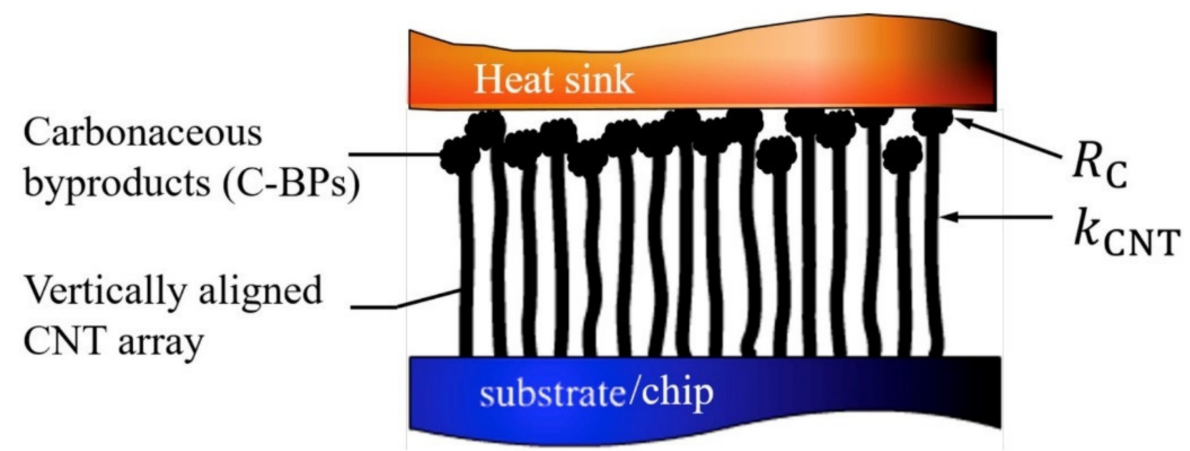

Figure 3. Construction of a thermal interface material (TIM) and the key parameters influencing heat transport [148]; copyright Elsevier (2017).

Analysis of the state of the art shows that vertically aligned CNT arrays are mostly employed in this field as they consist of CNTs that are directed appropriately [147-156]. The thermal conductivity along the CNT axis is higher by orders of magnitude than in the radial direction. Nevertheless, some findings remain universal, so they should be mentioned in order to understand the thermal characteristics of the CNT film. First, Taphouse and co-workers showed that the issue with high thermal resistance at the interface may be alleviated by applying polystyrene and poly-3-hexylthiophene to enhance the contact area available for heat transfer. Alternatively, a forest composed of large-diameter CNTs may be employed to improve the contact with the heat sink [150]. This ensures that the amount of thermally insulating voids in the material is minimized. Furthermore, CNT arrays can also be coated using diamond-like carbon and titanium nitride, which further decreases the thermal contact resistance between the array and the heat sink by removing the gaps otherwise filled with air. Other components based on metals such as Ni [151,152,156], Cu [157], Ag [153,154], or Au [155] can also facilitate heat exchange. Alternatively, as revealed by Qiu and co-workers, the material can be shear pressed to reorient the CNTs. The area of contact with the heat sink increases without the need 
to employ any other chemical compounds or elements [158]. A seven-fold increase in in-plane thermal conductivity and a four-fold decrease in the thermal contact resistance were observed..

Chen and colleagues showed how CNT films obtained by vacuum filtration could be used as a TIM [159]. They observed that the use of large-diameter MWCNTs is beneficial as compared with longer CNTs of smaller diameter. Interestingly, the authors noticed that the thermal conductivity of the network improved with shortening the length of the large-diameter MWCNTs by sonication. As a consequence, the density of the film was increased and the thermal impedance was reduced.

Therefore, the results show that isotropic CNT networks can also offer appreciable performance for heat dissipation, but further work is necessary on this front. These materials are commonly much more durable than vertically aligned CNT arrays and can be easily produced at a large scale, so their utility on this front remains to be elucidated.

\subsubsection{Thermoelectrics}

CNTs exhibit the Seebeck effect, which means that if they are exposed to a temperature gradient, an electric potential builds up in the material. From the practical perspective, this means that CNT ensembles can convert heat to useful electrical energy. There is an excellent review by Blackburn and co-workers demonstrating the potential of CNTs in this area [160]. Similarly, as in the case of CNT films used simply as conductive networks, the properties of individual CNTs differ from their macroscopic ensembles in terms of their thermoelectric properties. Constituting CNTs have a defined length, which gives rise to the creation of junctions between them, negatively affecting the material's ability to transport charge carriers and phonons. Hung et al. calculated that an individual semiconducting SWCNT of less than $0.6 \mathrm{~nm}$ in diameter should exhibit Sebeeck coefficients exceeding $2000 \mu \mathrm{V} / \mathrm{K}$ [161]. Unfortunately, due to the aforementioned constraints, such a value is unattainable in the case of CNT films. Furthermore, a considerable complication is that optimizing the material's parameters to reach the highest possible thermopower (quantified by the so-called Figure of Merit zT) depends on a set of intertwined characteristics (Figure 4).

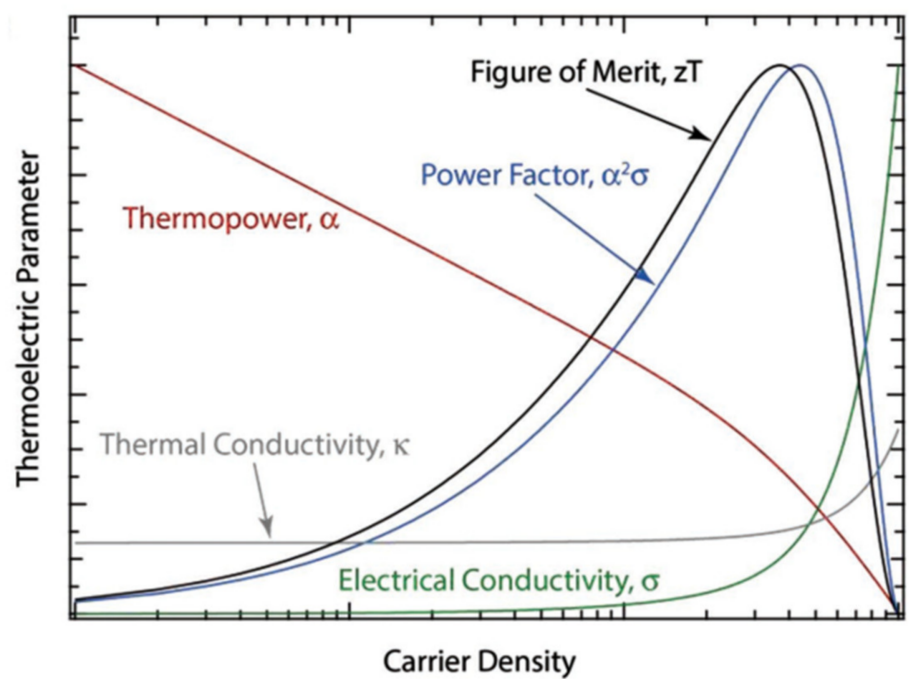

Figure 4. The interdependence of parameters of thermoelectric materials [160]; copyright WileyVCH (2018).

A perfect thermoelectric material should have both a high electrical conductivity and Seebeck coefficient while ensuring that the thermal conductivity is as low as possible. The low thermal conductivity of the material guarantees that the temperature gradient used to create an electric potential does not vanish rapidly during prolonged thermal energy harvesting. Various measures are executed to reach a trade-off between these factors. 
First of all, the material of high purity must be selected to minimize the scattering effect, which would negatively affect these characteristics. To meet this condition, highquality SWCNTs are most commonly employed. Additionally, the use of SWCNTs has a key advantage, as it enables one to sort the material by the characteristics of electrical conductivity or chirality [76]. Furthermore, despite their higher price, they commonly offer orders of magnitude higher performance than MWCNTs.

Semiconducting SWCNTs have high Seebeck coefficients, while metallic SWCNTs typically display high electrical conductivity. Piao and colleagues investigated the dependence of thermoelectric performance on the metallicity of CNT films [162]. The results showed that the metallic CNT films had a slightly higher electrical conductivity, but their Seebeck coefficient was almost 7-fold lower than that of the corresponding semiconducting SWCNTs. As the power factor used to gauge the material's thermoelectric capabilities is linearly and quadratically dependent on the electrical conductivity and Seebeck coefficient, respectively, the difference in performance was even more notable. Consequently, the semiconducting SWCNT films outperformed the metallic SWCNT films by a factor of 40 . Interestingly, as revealed by Lian et al., the thermal conductivity of both these types of networks can be comparable and dependent mostly on the length of SWCNTs constituting the network [163].

Another approach to how the carrier density can be modulated to enhance the thermoelectric performance of CNT films is to dope the material. Nonoguchi et al. illustrated how various chemical compounds could be used to tune this parameter [164]. Depending on the doping species structure, the electrical conductivity of the network may be significantly improved. Furthermore, in some cases, the conductivity characteristics are changed, which is manifested by the emergence of negative Seebeck coefficients. In such a scenario, the CNT films are strongly n-doped. One must keep in mind that under ambient conditions, the neat CNT ensembles are p-doped with oxygen $[165,166]$, so n-doping must be powerful enough to overcome this effect. As a consequence of incorporating the doping agents, the power factors of films constructed from SWCNTs experienced up to a three-fold increase.

\subsubsection{Electrothermics}

Alternatively, heat can be generated from CNT films due to Joule heating [78,167-172]. CNT films are highly flexible, and their temperature can be readily controlled by applying a sufficiently high electric current to induce charge scattering (Figure 5).
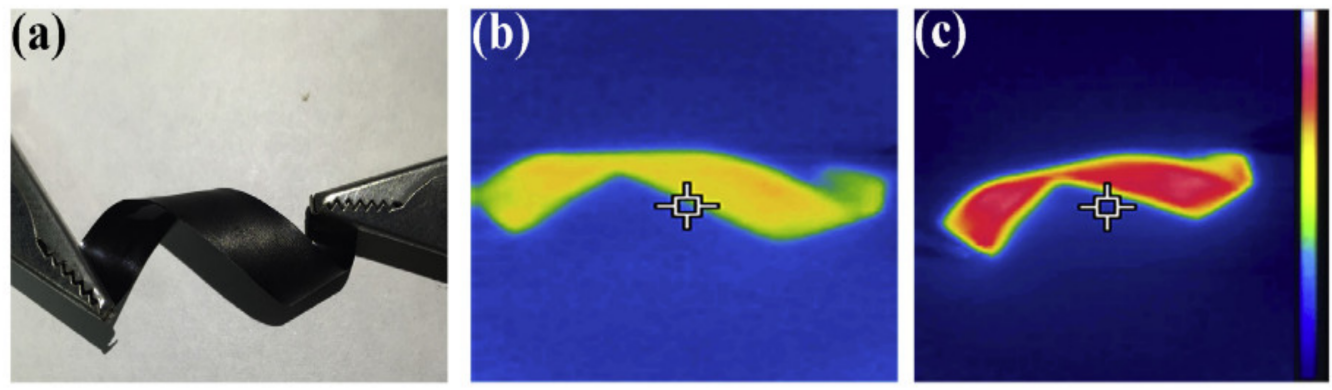

Figure 5. (a) An image of a twisted CNT film; IR camera images of the same CNT film heated to (b) medium and (c) high temperatures [173]; copyright Elsevier (2018).

CNT films have a low specific heat capacity, so they can heat up and cool down rapidly [78]. The heat response rate upon turning the current on or off exceeds $3000{ }^{\circ} \mathrm{C} / \mathrm{s}$. Furthermore, these materials can be easily patterned [174,175], so heat delivery can be made very specific to reach only the targeted locations.

In the electrothermal application of CNT films, the previously discussed junction resistance is advantageous, as it promotes the charge scattering effect, which facilitates the transformation of electrical energy into heat [176-178]. Regarding operational conditions, the employed current densities should not be excessive, as they can either etch CNTs 
layer by layer $[177,179]$ or eradicate the metallic fraction $[180,181]$, which has a higher conductivity, so it experiences a higher temperature due to larger current densities. As a consequence, the heating device may break down.

Due to the lightweight characteristic of CNT films, it is envisioned that the generated heat can be utilized in various applications in which weight is essential. An example of such an implementation area is the issue of aircraft de-icing, which may utilize high temperatures to melt it. Proofs of concept have already shown how resistively heated CNT films can be employed to tackle this challenge $[78,182]$. Moreover, CNT networks can be used in heated textiles [172]. The application of such material enables uniform heat delivery, which is beneficial to the user. This is a considerable improvement over the widely available heated clothes using resistive wires made up of nichrome or kanthal, which warm only the parts of the body which are in immediate contact with the wires. An attempt to increase the temperature of the wires (by employing a higher current) to cover the other areas is typically not a viable solution. It may result in local overheating, which is uncomfortable. Thus, CNT films are promising for heated textiles.

\subsection{Radiant Energy}

The full tunability in terms of the microstructure and composition of CNT films enables one to adjust their rich optical properties [183,184]. This section highlights how such ensembles can be used in solar cells and EMI (Electromagnetic interference) shielding structures due to their high optical absorption capabilities.

\subsubsection{Solar Energy}

As indicated in a recent review by Wieland and colleagues [185], CNTs, in theory, could replace all solar cell components. However, practical experience shows that this is not recommended at present, as a higher performance can be obtained when CNTs are interfaced with other materials. Due to their auspicious optical and electrical properties, thin CNT films have been considered as electrodes or hole transport layers. In such cases, it was already possible to establish Power Conversion Efficiencies (PCEs) matching or exceeding 13\% [186]. Even higher PCEs have already been reported in perovskite-based solar cells containing CNTs, which approach the level of 20\% [187-189].

Recent advances on the front of CNT sorting makes surpassing these values highly probable in the upcoming future $[76,190]$. Isborn and co-workers demonstrated how the use of chirality-resolved CNTs is beneficial for fullerene-containing solar cells [191]. The authors compared the performance of solar cells as a function of selected CNT chirality. Out of the evaluated thin layers composed of $(6,5),(7,6)$, and $(9,7) \mathrm{CNTs}$, the former exhibited the highest PCE because the alignment of energy levels between $(6,5)$ CNTs and $\mathrm{C}_{60}$ is the greatest, thereby increasing the likelihood of exciton separation and charge transfer from the SWCNT to $\mathrm{C}_{60}$.

\subsubsection{EMI Shielding}

The defense industry continually seeks materials and solutions which could provide critical advantages on the battlefield. Due to the peculiar way in which carbon materials interact with light, they are perfect candidates for applications in stealth technology. For a material to succeed in such a scenario, it must interact with the incoming radiation to reflect, absorb, and disperse it in an optimum way [192]. A schematic of the EMI shielding mechanics is presented in Figure 6. Ideally, the stealth material should absorb the radiation, with simultaneous dissipation of the generated heat as a result. The convolution of these parameters (absorption, transmission, and reflection) makes it challenging to find a suitable material, but CNTs seem to be a viable candidate. The potential of CNTs was quickly realized when the scientists noticed that to reach the same shielding effectiveness, one must add $10 \%$ wt of carbon black, $5 \%$ wt carbon fibers, or only $1 \%$ wt of MWCNTs [193]. Another milestone was reached when scientists observed that the light absorption capabilities of 
CNTs could also be tuned by the modification of the microstructure and composition, which can give rise to absorption values of $99.995 \%$ or more [194].

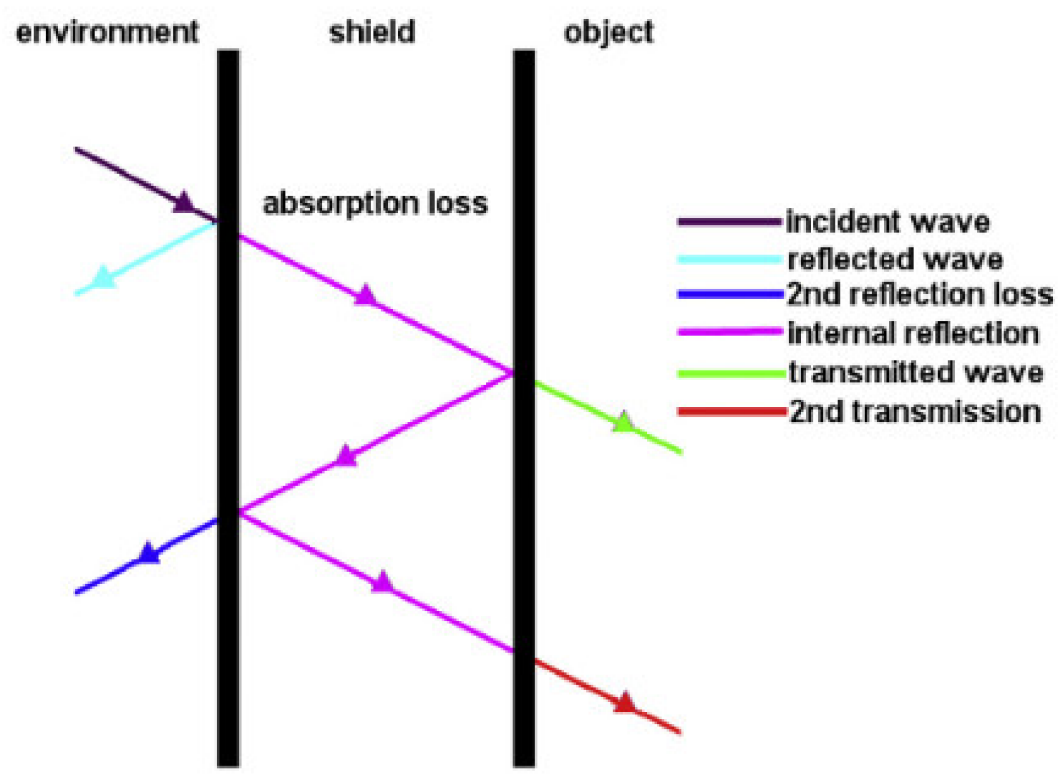

Figure 6. The operation of an EMI shielding material [192]. Copyright Elsevier (2018).

The versatility of MWCNT formulations and a plethora of possible composite combinations with polymers enable one to produce solutions for diverse RADAR ranges, including UHF [195], L [196], S [197], X [198-200], $K_{U}$ [201,202], K [203], and $K_{A}$ [192,204]. Often, metal particles are added, such as Fe [205], Ni [206], or Co [207], to enhance shielding properties.

Recently, several interesting contributions have emerged in this area. Feng et al. showed that CNTs can be interfaced with cellulose to produce a material of high EMI shielding effectiveness [208]. The authors investigated the influence of the CNT structure, and SWCNTs showed a higher performance than MWCNTs. When the materials' density was considered, an extremely high specific EMI SE value of about $7678 \mathrm{~dB} \mathrm{~cm}^{2} \mathrm{~g}^{-1}$ was obtained. Interestingly, when CNT films contained polyaniline, a one order of magnitude higher value was recorded, i.e., $7.5 \times 10^{4} \mathrm{~dB} \mathrm{~cm}^{2} \mathrm{~g}^{-1}$ [14]. Since a considerable share of interest is devoted to developing stealth technologies for aviation and aerospace, these findings are promising, as they offer solutions virtually free of weight burden. Moreover, Chikyu et al. recently illustrated the impact of CNT alignment on EMI shielding capabilities [209]. Due to high anisotropy, the composite at $2 \%$ of CNT encapsulated by PE loading showed a high attenuation exceeding $50 \mathrm{~dB}$ at $10 \mathrm{GHz}$. Lastly, Wan and colleagues investigated the performance of an ultrathin densified CNT film with metallic characteristics [210]. Shielding effectiveness of over $50 \mathrm{~dB}$ was achieved at a minimal thickness of $1.85 \mu \mathrm{m}$, proving that CNT films have high application potential in this field.

\subsubsection{Photocatalysis}

CNTs can also be an important component of photocatalysts, which, as the name implies, exploits radiant energy to facilitate chemical transformations. The source of this energy can either be solar or created artificially to adjust its characteristics to the optical properties of the employed CNT types. Murakami and co-workers showed how hydrogen can be produced from water when fullerodendron-coated SWCNTs are excited with monochromatic light [211]. In this study, monochiral SWCNTs were coated first with a layer of dendron-modified $\mathrm{C}_{60}$ fullerenes, and then with Pt nanoparticles as a cocatalyst. The best results were obtained when a $(8,3)$ SWCNT-based catalytic system was irradiated with light of $680 \mathrm{~nm}$ in wavelength, which corresponds to the $\mathrm{E}_{22}$ absorption band of this chirality. The same team subsequently reported that $\mathrm{Ru}$ particles can be used instead of $\mathrm{Pt}$ [212]. When coupled with $\mathrm{BiVO}_{4}$ as an $\mathrm{O}_{2}$-evolving photocatalyst, and a 
Co complex $\left(\left[\mathrm{Co}(\mathrm{bpy})_{3}\right]^{3+/ 2+}\right.$ ) as an electron mediator, substantial $\mathrm{H}_{2}$ and $\mathrm{O}_{2}$ evolution as a result of water splitting was observed under irradiation from visible light. There was no need to employ any sacrificial agents or external bias. Later, these researchers also demonstrated that photocatalytic activity can be enhanced by the encapsulation of a ferrocenyl-based photosensitizer inside of the SWCNT cavity [213]. In the literature, one can find reports engaging many other types of materials capable of improving the photocatalytic characteristics of CNTs, such as graphite carbon nitride [214], CdS [215], or $\mathrm{TiO}_{2}$ [216], for hydrogen evolution. Readers interested in investigating this concept further are advised to refer to dedicated reviews on this topic $[217,218]$.

The same principle can be used to reduce $\mathrm{CO}_{2}$, which is the main greenhouse gas resulting from human activities [219], to useful chemical compounds, such as methanol, ethanol, methane, or carbon monoxide. A wide spectrum of photocatalytic formulations employing CNTs for this purpose has been reported [220]. CNTs are often decorated with $\mathrm{TiO}_{2}$, the combination of which provides appreciable performance [221-223]. The activity could be modulated by the addition of $\mathrm{Cu}$ [221] or Ni [222], which may scavenge the photoexcited electrons, thereby retarding the recombination process. Lashgari and colleagues showed how $\mathrm{ZnO} / \mathrm{CuO} / \mathrm{CNT}$ composite material promotes the conversion of $\mathrm{CO}_{2}$ into oxygenate fuels, such as ethanol, oxalic acid, and formaldehyde [224]. In this solution, $\mathrm{CuO}$ and $\mathrm{ZnO}$ acted as $\mathrm{p}$ - and n-type semiconductors, respectively, responsible for charge separation, whereas the CNT provided a surface area for the reaction and facilitated charge mobility. The utility of metal-based species is not limited to oxides, but it extends to their halides [225], phosphides [226], complexes with porphyrins [227], etc.

\subsection{Mechanical Energy}

Due to their excellent mechanical properties [228,229], CNT films can also be used in a wide spectrum of applications, wherein they are subjected to deformation. High strength and flexibility enable one to employ such networks to transform mechanical to electrical energy (piezoelectrics) and vice versa (actuators). The sections below display how CNTs perform on this front.

\subsubsection{Piezoelectrics}

Flexible piezoelectric nanocomposites have been at the focal point of researchers for a long time. Many groups have tried to improve the electrical properties of typical polymer-based piezoelectric materials material by tuning the piezoelectric and dielectric characteristics in particular [230,231]. It was recently found that the addition of a conductive filler could facilitate the device's polarization, thereby enhancing its performance $[232,233]$. The high aspect ratio of the CNTs makes them a promising material to include, as they can afford the percolation of the composite at a relatively low loading and exhibit appropriate dielectric constants [234]. For instance, Kim and Kim showed that the addition of MWCNTs to ceramic-epoxy nanocomposites produces thin films of doubled piezoelectric coefficients reaching $68 \mathrm{pC} / \mathrm{N}\left(\mathrm{d}_{33}\right)$ and $434 \mathrm{mV} \cdot \mathrm{m} / \mathrm{N}\left(\mathrm{g}_{33}\right)$ [235]. At just $0.07 \mathrm{wt} \%$ of MWCNTs, the device's output voltage amounted to $575.42 \mathrm{mV}$ under $1 \mathrm{~N}$, and the film produced from these materials was highly flexible. Furthermore, the blending of ceramics, PTFE, and MWCNTs was also found to be useful [236]. The favorable action of MWCNTs in these three-component piezoelectric materials was further verified by others using different formulations [237]. In all cases, the addition of MWCNTs was particularly beneficial, as it ensured the device's high flexibility and durability. Gau et al. showed that the combination of polyimide and MWCNTs provides a polymer-based pressure sensor of linear piezoelectric nature [238]. The authors demonstrated that the change of pressure from 0 to $400 \mathrm{kPa}$ could be well gauged by monitoring the device's electrical resistance. Interestingly, the MWCNTs themselves seem to contribute to the temperature dependence of piezoelectric characteristics [239]. Cao and colleagues reported that pure MWCNT films experienced a notable increase in their gauge factor when the temperature was elevated from 15 to $50{ }^{\circ} \mathrm{C}$. Such findings encouraged scientists to consider the development of 
devices in which CNTs would serve the role of the matrix, not the filler. An interesting study was conducted by Chen and co-workers, who integrated CNT films with PVA and interfaced them with a layer of $\mathrm{ZnO}$ nanowires [240]. The material revealed high piezoresistive sensitivity and linear stability at different PVA loadings. An 100\% PVA loading with respect to CNTs produced a device of piezoresistive sensitivity and linear stability of $11.95 \% / \mathrm{mm}$ and $4.78 \%$, respectively. The proposed concept was also appropriate for the operation under impulse loading, making it promising for monitoring dynamic load applications. As a consequence, it could be used for structural health monitoring. Depending on the device configuration, CNT films can also play the role of substrate and current collector. Li et al. showed how aligned $\mathrm{ZnO}$ nanorods can be deposited on the surface of a CNT film (Figure 7) [241]. Schottky contacts were established between these two components, and the device itself reached appreciable piezoelectric performance.

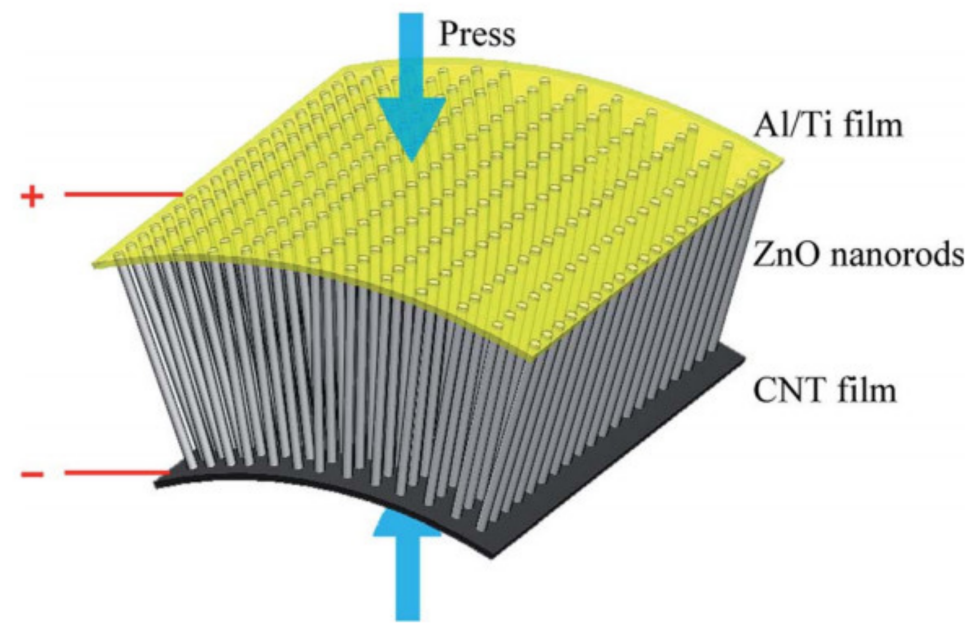

Figure 7. Scheme of a piezoelectric generator from metal/ZnO nanorods/CNT film [241]. Copyright the Royal Society of Chemistry (2014).

Finally, to reach the best piezoelectric performance, PVDF is typically employed due to its remarkable piezoelectric coefficients [242-245]. When combined with a proper amount of CNTs, the CNTs promote the formation of the PVDF $\beta$-phase [246]. This phase is more suitable for piezoelectric applications, since the $\mathrm{C}-\mathrm{H}$ and C-F dipole moments align and add up, enhancing the material's polarizability, which is essential for piezoelectrics. Kabir and co-workers showed that the presence of CNTs can give rise to the completely pure $(100 \%) \beta$-crystalline phase of PVDF [247]. Therefore, the development of CNT-containing materials for harvesting mechanical energy is justified.

\subsubsection{Actuators}

Perhaps among the earliest reports demonstrating the possibility of using CNTs as actuators was published by Baughman and co-workers [248]. In this influential paper, the authors showed that sheets produced from SWCNTs are capable of working like artificial muscles even in the absence of ion intercalation operating exclusively on the principle of quantum chemical-based expansion resulting from the electrochemical doublelayer charging. Since then, many similar solutions based on CNT films have emerged in the literature.

Ning et al. recently reported a different approach in which an aligned CNT/PI film can be manufactured and used as a fast heater and thermomechanical actuator [169]. Passing a sufficiently electric current through the network increases its temperature by Joule heating, thereby modifying its shape (Figure 8). 

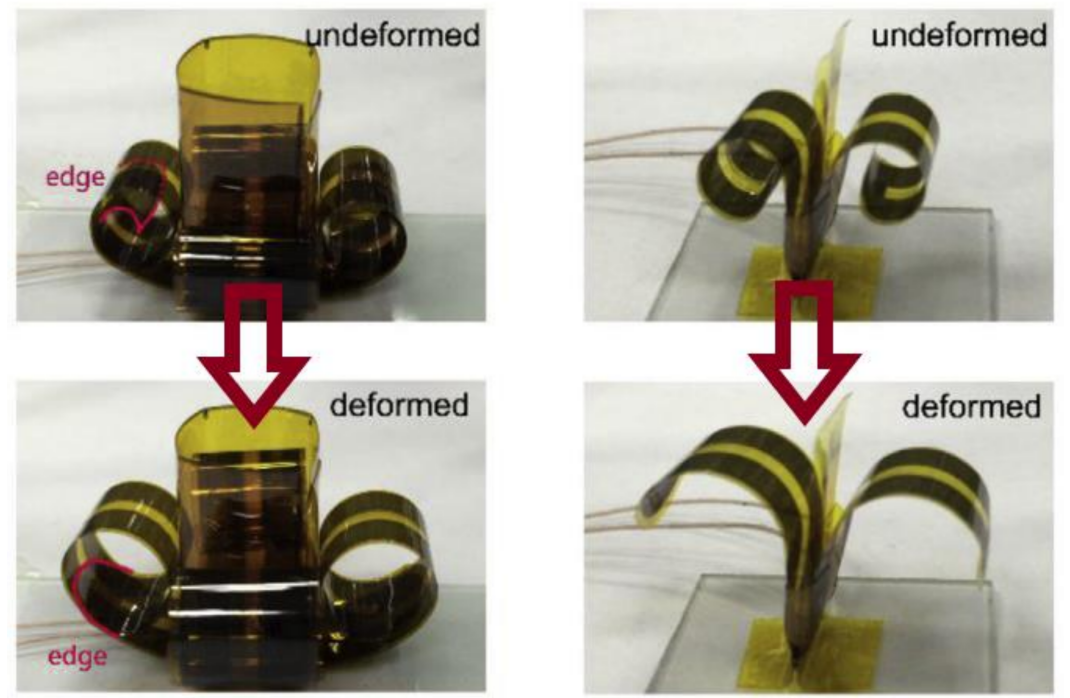

Figure 8. Electromechanical deformation of the actuators upon applying bias voltage [169]. Copyright Elsevier (2018).

Wang et al. showed how this concept could be exploited in a broader temperature regime [249] (Figure 9). A bilayer actuator was produced from CNTs and boron nitride (BN). Then, a high electrical current was delivered to the device kept under inert conditions. After only $100 \mathrm{~ms}$, due to very low heat capacity, the $10 \mu \mathrm{m}$-thick composite film's displacement was observed towards the BN side. Switching of the current resulted in shape restoration after another $100 \mathrm{~ms}$, during which the network cooled down to room temperature.

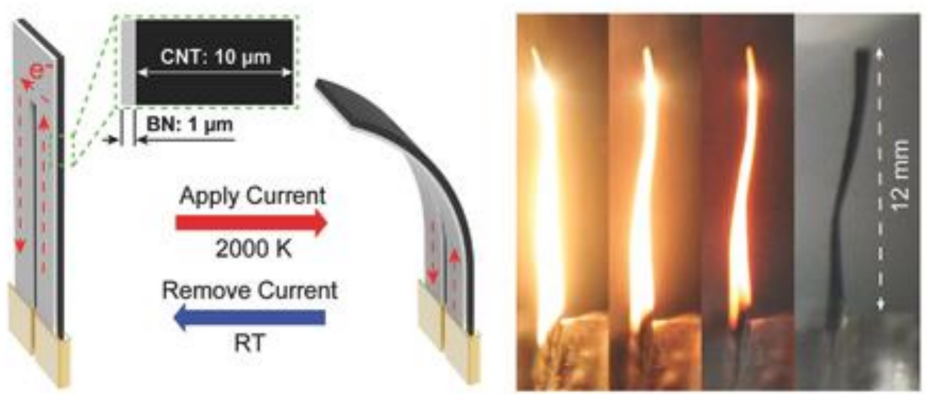

Figure 9. Electromechanical deformation of the actuators upon applying bias voltage under inert atmosphere [249]. Copyright Wiley (2016).

The combination of different materials can be incredibly beneficial. For instance, Amjadi and Sitti reported that paper actuators based on graphite and CNTs could offer self-sensing properties [250]. To obtain such functionality, the authors exploited differences in the Coefficients of Hygroscopic Expansion (CHE) and Coefficients of Thermal Expansion (CTE) of the components. Consequently, the device was able to recognize the touch of soft and hard objects. Lastly, Liang and colleagues recently disclosed that the actuating feature can be used to construct a biomimetic device capable of sensing location and having underwater locomotive skills [251]. To produce such a component for intelligent soft robotics, the authors sandwiched a CNT film between two polydimethylsiloxane (PDMS) layers producing a fully functional artificial swim bladder operating on the principles of reversible inflation and deflation. Such a hollow untethered actuating system demonstrated functions such as synchronous sensing over water depth and even detected tiny vibrations from the external environment. 


\section{Conclusions and Future Outlook}

Ever since they were discovered, CNTs have demonstrated a broad application potential. Even if one constrains the consideration to exclusively energy-related areas, the potential application of these nanostructures remains wide. It easily spans across diverse fields of science and technology dealing with energy generation or transformation. As demonstrated in this perspective article, CNTs assembled into thin films have high utility in managing or transforming electrical, thermal, radiant, and mechanical energy from one form to another. Often, they exhibit high performance in this regard.

Thirty years after Iijima's influential paper formally opening the CNT field, the community can witness that these nanostructures have finally become competitive with the traditional materials. Especially when weight is taken into account, there are many reports in which the specific electrical conductivity of CNT films has surpassed that of certain metallic species. Currently, prototypes based on them are evaluated under typical operational conditions to validate findings obtained in the laboratories. The successful verification of these outcomes at a large scale should soon enable them to reach a sufficient technology readiness level for deployment. This will probably start with their more niche application to eventually reach more domesticated fields of exploitation. In the case of semiconducting CNTs, first transistors produced from them have already managed to outperform silicon, which is highly promising for the future. In the long term, reaching this milestone should enable the manufacture of computing processing units, in which CNTs would be at the core.

Considerable advances have recently been achieved in the triad of great challenges faced by CNTs: alignment, chirality control, and reproducibility/scalability. The presented review shows that they form the common denominator hampering the broad implementation of CNTs in energy-related fields. Once we grasp the ability to produce CNT networks of predetermined chirality, alignment, and at a large scale, the route to replace typical materials used in the energy sector should be essentially clear of obstacles. During only three decades after their discovery, considerable progress has been made in these areas. As a consequence, the capabilities of CNT films to transform and generate energy has been greatly improved. If one takes into the account the time taken to progress well-known materials, such as steel, to the current level, the achievements on the nanocarbon front become relatively appreciable. We are only at the beginning of this challenging route, and, based on the provided evidence, it seems that the widespread implementation of CNT films is fast approaching.

Author Contributions: Conceptualization, D.J.; Data curation, D.J.; Formal analysis, M.R. and D.J.; Funding acquisition, D.J.; Investigation, D.J.; Methodology, D.J.; Project administration, D.J.; Resources, D.J.; Supervision, D.J.; Validation, D.J.; Visualization, M.R. and D.J.; Writing—original draft, M.R. and D.J. All authors have read and agreed to the published version of the manuscript.

Funding: D.J. would like to thank the National Centre for Research and Development, Poland (under the Leader program, grant agreement LIDER/0001/L-8/16/NCBR/2017), for financial support of the research.

Institutional Review Board Statement: Not applicable.

Informed Consent Statement: Not applicable.

Data Availability Statement: Data regarding this article are available from the corresponding author upon reasonable request.

Conflicts of Interest: The authors declare no conflict of interest. The funders had no role in the design of the study; in the collection, analyses, or interpretation of data; in the writing of the manuscript, or in the decision to publish the results. 


\section{References}

1. Ritchie, H.; Roser, M. Energy. Our World in Data. 2014. Available online: https:/ / ourworldindata.org/energy (accessed on 29 March 2021).

2. Pakdel, A.; Zhi, C.; Bando, Y.; Golberg, D. Low-Dimensional Boron Nitride Nanomaterials. Mater. Today 2012, 15, 256-265. [CrossRef]

3. Kufer, D.; Konstantatos, G. Photo-FETs: Phototransistors Enabled by 2D and 0D Nanomaterials. ACS Photonics 2016, 3, 2197-2210. [CrossRef]

4. Fang, L.; Feng, J.J.; Shi, X.; Si, T.; Song, Y.; Jia, H.; Li, Y.; Li, H.-W.; Zhang, Q. Turning Bulk Materials into 0D, 1D and 2D Metallic Nanomaterials by Selective Aqueous Corrosion. Chem. Commun. 2019, 55, 10476-10479. [CrossRef]

5. Rajendran, R.; Shrestha, L.K.; Minami, K.; Subramanian, M.; Jayavel, R.; Ariga, K. Dimensionally Integrated Nanoarchitectonics for a Novel Composite from 0D, 1D, and 2D Nanomaterials: RGO/CNT/CeO2 Ternary Nanocomposites with Electrochemical Performance. J. Mater. Chem. A 2014, 2, 18480-18487. [CrossRef]

6. Iijima, S. Helical Microtubules of Graphitic Carbon. Nature 1991, 354, 56-58. [CrossRef]

7. Novoselov, K.S.; Geim, A.K.; Morozov, S.V.; Jiang, D.; Zhang, Y.; Dubonos, S.V.; Grigorieva, I.V.; Firsov, A.A. Electric Field Effect in Atomically Thin Carbon Films. Science 2004, 306, 666-669. [CrossRef] [PubMed]

8. Brady, G.J.; Way, A.J.; Safron, N.S.; Evensen, H.T.; Gopalan, P.; Arnold, M.S. Quasi-Ballistic Carbon Nanotube Array Transistors with Current Density Exceeding Si and GaAs. Sci. Adv. 2016, 2, e1601240. [CrossRef] [PubMed]

9. Kumanek, B.; Janas, D. Thermal Conductivity of Carbon Nanotube Networks: A Review. J. Mater. Sci. 2019, 54, 7397-7427. [CrossRef]

10. Lee, C.; Wei, X.; Kysar, J.W.; Hone, J. Measurement of the Elastic Properties and Intrinsic Strength of Monolayer Graphene. Science 2008, 321, 385-388. [CrossRef] [PubMed]

11. Janas, D.; Koziol, K.K. A Review of Production Methods of Carbon Nanotube and Graphene Thin Films for Electrothermal Applications. Nanoscale 2014, 6, 3037-3045. [CrossRef] [PubMed]

12. Lekawa-Raus, A.; Patmore, J.; Kurzepa, L.; Bulmer, J.; Koziol, K. Electrical Properties of Carbon Nanotube Based Fibers and Their Future Use in Electrical Wiring. Adv. Funct. Mater. 2014, 24, 3661-3682. [CrossRef]

13. Wang, K.; Luo, S.; Wu, Y.; He, X.; Zhao, F.; Wang, J.; Jiang, K.; Fan, S. Super-Aligned Carbon Nanotube Films as Current Collectors for Lightweight and Flexible Lithium Ion Batteries. Adv. Funct. Mater. 2013, 23, 846-853. [CrossRef]

14. Li, H.; Lu, X.; Yuan, D.; Sun, J.; Erden, F.; Wang, F.; He, C. Lightweight Flexible Carbon Nanotube/Polyaniline Films with Outstanding EMI Shielding Properties. J. Mater. Chem. C 2017, 5, 8694-8698. [CrossRef]

15. Kanoun, O.; Müller, C.; Benchirouf, A.; Sanli, A.; Dinh, T.N.; Al-Hamry, A.; Bu, L.; Gerlach, C.; Bouhamed, A. Flexible Carbon Nanotube Films for High Performance Strain Sensors. Sensors 2014, 14, 10042-10071. [CrossRef]

16. Janas, D.; Vilatela, A.C.; Koziol, K.K.K. Performance of Carbon Nanotube Wires in Extreme Conditions. Carbon 2013, 62, 438-446. [CrossRef]

17. Janas, D.; Cabrero-Vilatela, A.; Bulmer, J.; Kurzepa, L.; Koziol, K.K. Carbon Nanotube Wires for High-Temperature Performance. Carbon 2013, 64, 305-314. [CrossRef]

18. Janas, D. From Bio to Nano: A Review of Sustainable Methods of Synthesis of Carbon Nanotubes. Sustainability 2020, $12,4115$. [CrossRef]

19. Kumar, S.; Nehra, M.; Kedia, D.; Dilbaghi, N.; Tankeshwar, K.; Kim, K.-H. Carbon Nanotubes: A Potential Material for Energy Conversion and Storage. Prog. Energy Combust. Sci. 2018, 64, 219-253. [CrossRef]

20. Sun, L.; Wang, X.; Wang, Y.; Zhang, Q. Roles of Carbon Nanotubes in Novel Energy Storage Devices. Carbon 2017, 122, 462-474. [CrossRef]

21. Yu, D.; Goh, K.; Wang, H.; Wei, L.; Jiang, W.; Zhang, Q.; Dai, L.; Chen, Y. Scalable Synthesis of Hierarchically Structured Carbon Nanotube-Graphene Fibres for Capacitive Energy Storage. Nat. Nanotechnol. 2014, 9, 555-562. [CrossRef]

22. Zhou, Y.; Azumi, R. Carbon Nanotube Based Transparent Conductive Films: Progress, Challenges, and Perspectives. Sci. Technol. Adv. Mater. 2016, 17, 493-516. [CrossRef]

23. Yu, L.; Shearer, C.; Shapter, J. Recent Development of Carbon Nanotube Transparent Conductive Films. Chem. Rev. 2016, 116, 13413-13453. [CrossRef] [PubMed]

24. Rossell, M.D.; Kuebel, C.; Ilari, G.; Rechberger, F.; Heiligtag, F.J.; Niederberger, M.; Koziej, D.; Erni, R. Impact of Sonication Pretreatment on Carbon Nanotubes: A Transmission Electron Microscopy Study. Carbon 2013, 61, 404-411. [CrossRef]

25. Graf, A.; Zakharko, Y.; Schießl, S.P.; Backes, C.; Pfohl, M.; Flavel, B.S.; Zaumseil, J. Large Scale, Selective Dispersion of Long Single-Walled Carbon Nanotubes with High Photoluminescence Quantum Yield by Shear Force Mixing. Carbon 2016, 105, 593-599. [CrossRef]

26. Datsyuk, V.; Kalyva, M.; Papagelis, K.; Parthenios, J.; Tasis, D.; Siokou, A.; Kallitsis, I.; Galiotis, C. Chemical Oxidation of Multiwalled Carbon Nanotubes. Carbon 2008, 46, 833-840. [CrossRef]

27. Singer, G.; Siedlaczek, P.; Sinn, G.; Rennhofer, H.; Mičušík, M.; Omastová, M.; Unterlass, M.M.; Wendrinsky, J.; Milotti, V.; Fedi, F.; et al. Acid Free Oxidation and Simple Dispersion Method of MWCNT for High-Performance CFRP. Nanomaterials 2018, 8, 912. [CrossRef] [PubMed]

28. Zhang, J.; Gao, L. Dispersion of Multiwall Carbon Nanotubes by Sodium Dodecyl Sulfate for Preparation of Modified Electrodes toward Detecting Hydrogen Peroxide. Mater. Lett. 2007, 61, 3571-3574. [CrossRef] 
29. Yang, K.; Yi, Z.; Jing, Q.; Yue, R.; Jiang, W.; Lin, D. Sonication-Assisted Dispersion of Carbon Nanotubes in Aqueous Solutions of the Anionic Surfactant SDBS: The Role of Sonication Energy. Chin. Sci. Bull. 2013, 58, 2082-2090. [CrossRef]

30. Keinänen, P.; Siljander, S.; Koivula, M.; Sethi, J.; Sarlin, E.; Vuorinen, J.; Kanerva, M. Optimized Dispersion Quality of Aqueous Carbon Nanotube Colloids as a Function of Sonochemical Yield and Surfactant/CNT Ratio. Heliyon 2018, 4, e00787. [CrossRef]

31. Parveen, S.; Rana, S.; Fangueiro, R.; Paiva, M.C. Characterizing Dispersion and Long Term Stability of Concentrated Carbon Nanotube Aqueous Suspensions for Fabricating Ductile Cementitious Composites. Powder Technol. 2017, 307, 1-9. [CrossRef]

32. Mirri, F.; Ma, A.W.K.; Hsu, T.T.; Behabtu, N.; Eichmann, S.L.; Young, C.C.; Tsentalovich, D.E.; Pasquali, M. High-Performance Carbon Nanotube Transparent Conductive Films by Scalable Dip Coating. ACS Nano 2012, 6, 9737-9744. [CrossRef]

33. Song, Y.I.; Kim, G.Y.; Choi, H.K.; Jeong, H.J.; Kim, K.K.; Yang, C.-M.; Lim, S.C.; An, K.H.; Jung, K.T.; Lee, Y.H. Fabrication of Carbon Nanotube Field Emitters Using a Dip-Coating Method. Chem. Vap. Depos. 2006, 12, 375-379. [CrossRef]

34. Kim, P.; Kang, T.J. Large-Area Fluidic Assembly of Single-Walled Carbon Nanotubes through Dip-Coating and Directional Evaporation. Micro Nano Syst. Lett. 2017, 5, 18. [CrossRef]

35. Kang, T.J.; Yoon, J.-W.; Kim, D.-I.; Kum, S.S.; Huh, Y.-H.; Hahn, J.-H.; Moon, S.H.; Lee, H.-Y.; Kim, Y.H. Sandwich-Type Laminated Nanocomposites Developed by Selective Dip-Coating of Carbon Nanotubes. Adv. Mater. 2007, 19, 427-432. [CrossRef]

36. Spotnitz, M.E.; Ryan, D.; Stone, H.A. Dip Coating for the Alignment of Carbon Nanotubes on Curved Surfaces. J. Mater. Chem. 2004, 14, 1299-1302. [CrossRef]

37. Pyo, S.; Jo, E.; Kwon, D.; Kim, W.; Chang, W.; Kim, J. Fabrication of Carbon Nanotube-Coated Fabric for Highly Sensitive Pressure Sensor. In Proceedings of the 2017 19th International Conference on Solid-State Sensors, Actuators and Microsystems (TRANSDUCERS), Kaohsiung, Taiwan, 18-22 June 2017; pp. 962-965.

38. Tchoul, M.N.; Ford, W.T.; Ha, M.L.P.; Chavez-Sumarriva, I.; Grady, B.P.; Lolli, G.; Resasco, D.E.; Arepalli, S. Composites of Single-Walled Carbon Nanotubes and Polystyrene: Preparation and Electrical Conductivity. Chem. Mater. 2008, 20, 3120-3126. [CrossRef]

39. Song, Y.I.; Yang, C.-M.; Kim, D.Y.; Kanoh, H.; Kaneko, K. Flexible Transparent Conducting Single-Wall Carbon Nanotube Film with Network Bridging Method. J. Colloid Interface Sci. 2008, 318, 365-371. [CrossRef] [PubMed]

40. WU, B.; BAI, L. Effect of Non-Ionic Surfactants on the Dispersion of Multiwalled Carbon Nanotubes at High Loading in Ethanol. Acta Phys. Chim. Sin. 2009, 25, 1065-1069.

41. Meyer, F.; Minoia, A.; Raquez, J.M.; Spasova, M.; Lazzaroni, R.; Dubois, P. Poly(Amino-Methacrylate) as Versatile Agent for Carbon Nanotube Dispersion: An Experimental, Theoretical and Application Study. J. Mater. Chem. 2010, 20, 6873-6880. [CrossRef]

42. Liu, L.; Han, J.; Xu, L.; Zhou, J.; Zhao, C.; Ding, S.; Shi, H.; Xiao, M.; Ding, L.; Ma, Z.; et al. Aligned, High-Density Semiconducting Carbon Nanotube Arrays for High-Performance Electronics. Science 2020, 368, 850-856. [CrossRef]

43. Kerdcharoen, T.; Wongchoosuk, C. 11-Carbon nanotube and metal oxide hybrid materials for gas sensing. In Semiconductor Gas Sensors; Jaaniso, R., Tan, O.K., Eds.; Woodhead Publishing Series in Electronic and Optical Materials; Woodhead Publishing: Cambridge, UK; Sawston, UK, 2013; pp. 386-407. ISBN 978-0-85709-236-6.

44. Park, J.-M.; Wang, Z.-J.; Kwon, D.-J.; Gu, G.-Y.; Lawrence DeVries, K. Electrical Properties of Transparent CNT and ITO Coatings on PET Substrate Including Nano-Structural Aspects. Solid-State Electron. 2013, 79, 147-151. [CrossRef]

45. Cha, J.E.; Kim, S.Y.; Lee, S.H. Effect of Continuous Multi-Walled Carbon Nanotubes on Thermal and Mechanical Properties of Flexible Composite Film. Nanomaterials 2016, 6, 182. [CrossRef] [PubMed]

46. Fischer, T.; Wetzold, N.; Elsner, H.; Kroll, L.; Hübler, A.C. Carbon Nanotube Areas—Printed on Textile and Paper Substrates. Nanomater. Nanotechnol. 2011, 1, 3. [CrossRef]

47. Boccaccini, A.R.; Cho, J.; Roether, J.A.; Thomas, B.J.C.; Jane Minay, E.; Shaffer, M.S.P. Electrophoretic Deposition of Carbon Nanotubes. Carbon 2006, 44, 3149-3160. [CrossRef]

48. Liu, K.; Sun, Y.; Liu, P.; Wang, J.; Li, Q.; Fan, S.; Jiang, K. Periodically Striped Films Produced from Super-Aligned Carbon Nanotube Arrays. Nanotechnology 2009, 20, 335705. [CrossRef] [PubMed]

49. Janas, D.; Koziol, K.K. Carbon Nanotube Fibers and Films: Synthesis, Applications and Perspectives of the Direct-Spinning Method. Nanoscale 2016, 8, 19475-19490. [CrossRef]

50. Kymakis, E.; Stylianakis, M.M.; Spyropoulos, G.D.; Stratakis, E.; Koudoumas, E.; Fotakis, C. Spin Coated Carbon Nanotubes as the Hole Transport Layer in Organic Photovoltaics. Sol. Energy Mater. Sol. Cells 2012, 96, 298-301. [CrossRef]

51. Jo, J.W.; Jung, J.W.; Lee, J.U.; Jo, W.H. Fabrication of Highly Conductive and Transparent Thin Films from Single-Walled Carbon Nanotubes Using a New Non-Ionic Surfactant via Spin Coating. ACS Nano 2010, 4, 5382-5388. [CrossRef] [PubMed]

52. Holubowitch, N.E.; Landon, J.; Lippert, C.A.; Craddock, J.D.; Weisenberger, M.C.; Liu, K. Spray-Coated Multiwalled Carbon Nanotube Composite Electrodes for Thermal Energy Scavenging Electrochemical Cells. ACS Appl. Mater. Interfaces 2016, 8, 22159-22167. [CrossRef]

53. Tuukkanen, S.; Välimäki, M.; Lehtimäki, S.; Vuorinen, T.; Lupo, D. Behaviour of One-Step Spray-Coated Carbon Nanotube Supercapacitor in Ambient Light Harvester Circuit with Printed Organic Solar Cell and Electrochromic Display. Sci. Rep. 2016, 6, 22967. [CrossRef]

54. Park, C.; Kim, S.W.; Lee, Y.-S.; Lee, S.H.; Song, K.H.; Park, L.S. Spray Coating of Carbon Nanotube on Polyethylene Terephthalate Film for Touch Panel Application. J. Nanosci. Nanotechnol. 2012, 12, 5351-5355. [CrossRef] [PubMed] 
55. Jeong, M.; Lee, K.; Choi, E.; Kim, A.; Lee, S.-B. Spray-Coated Carbon Nanotube Thin-Film Transistors with Striped Transport Channels. Nanotechnology 2012, 23, 505203. [CrossRef]

56. Tutak, W.; Chhowalla, M.; Sesti, F. The Chemical and Physical Characteristics of Single-Walled Carbon Nanotube Film Impact on Osteoblastic Cell Response. Nanotechnology 2010, 21, 315102. [CrossRef] [PubMed]

57. Sangwan, V.K.; Ortiz, R.P.; Alaboson, J.M.P.; Emery, J.D.; Bedzyk, M.J.; Lauhon, L.J.; Marks, T.J.; Hersam, M.C. Fundamental Performance Limits of Carbon Nanotube Thin-Film Transistors Achieved Using Hybrid Molecular Dielectrics. ACS Nano 2012, 6, 7480-7488. [CrossRef]

58. Zhang, J.; Jiang, D.; Peng, H.-X. A Pressurized Filtration Technique for Fabricating Carbon Nanotube Buckypaper: Structure, Mechanical and Conductive Properties. Microporous Mesoporous Mater. 2014, 184, 127-133. [CrossRef]

59. Rojas, J.A.; Ardila-Rodríguez, L.A.; Diniz, M.F.; Gonçalves, M.; Ribeiro, B.; Rezende, M.C. Highly Porous Multiwalled Carbon Nanotube Buckypaper Using Electrospun Polyacrylonitrile Nanofiber as a Sacrificial Material. Heliyon 2019, 5, e01386. [CrossRef]

60. Xu, G.-H.; Zhang, Q.; Huang, J.-Q.; Zhao, M.-Q.; Zhou, W.-P.; Wei, F. A Two-Step Shearing Strategy to Disperse Long Carbon Nanotubes from Vertically Aligned Multiwalled Carbon Nanotube Arrays for Transparent Conductive Films. Langmuir 2010, 26, 2798-2804. [CrossRef]

61. He, X.; Gao, W.; Xie, L.; Li, B.; Zhang, Q.; Lei, S.; Robinson, J.M.; Hároz, E.H.; Doorn, S.K.; Wang, W.; et al. Wafer-Scale Monodomain Films of Spontaneously Aligned Single-Walled Carbon Nanotubes. Nat. Nanotechnol. 2016, 11, 633-638. [CrossRef] [PubMed]

62. Cao, C.; Andrews, J.B.; Kumar, A.; Franklin, A.D. Improving Contact Interfaces in Fully Printed Carbon Nanotube Thin-Film Transistors. ACS Nano 2016, 10, 5221-5229. [CrossRef]

63. Lakshmanan, S.; Kanwal, A.; Liu, S.; Patlolla, A.; Iqbal, Z.; Mitra, S.; Thomas, G.A.; Fagan, J.A.; Farrow, R.C. Improved Electrophoretic Deposition of Vertical Single Wall Carbon Nanotubes with Nanoscopic Electrostatic Lenses. Micromachines 2020, 11, 324. [CrossRef]

64. Thomas, B.J.C.; Shaffer, M.S.P.; Freeman, S.; Koopman, M.; Chawla, K.K.; Boccaccini, A.R. Electrophoretic Deposition of Carbon Nanotubes on Metallic Surfaces. Available online: https:/ / www.scientific.net/KEM.314.141 (accessed on 4 February 2021).

65. Choi, W.B.; Jin, Y.W.; Kim, H.Y.; Lee, S.J.; Yun, M.J.; Kang, J.H.; Choi, Y.S.; Park, N.S.; Lee, N.S.; Kim, J.M. Electrophoresis Deposition of Carbon Nanotubes for Triode-Type Field Emission Display. Appl. Phys. Lett. 2001, 78, 1547-1549. [CrossRef]

66. Qingliang, S.; Hejun, L.; Fengling, Z.; Qiang, S.; Qiangang, F. Electrophoretic Deposition of Carbon Nanotubes for Improved Ablation Resistance of Carbon/Carbon Composites. Corros. Sci. 2018, 132, 204-213. [CrossRef]

67. Pöhls, J.-H.; Johnson, M.B.; White, M.A.; Malik, R.; Ruff, B.; Jayasinghe, C.; Schulz, M.J.; Shanov, V. Physical Properties of Carbon Nanotube Sheets Drawn from Nanotube Arrays. Carbon 2012, 50, 4175-4183. [CrossRef]

68. Zhang, X.; Jiang, K.; Feng, C.; Liu, P.; Zhang, L.; Kong, J.; Zhang, T.; Li, Q.; Fan, S. Spinning and Processing Continuous Yarns from 4-Inch Wafer Scale Super-Aligned Carbon Nanotube Arrays. Adv. Mater. 2006, 18, 1505-1510. [CrossRef]

69. Li, Y.-L.; Kinloch, I.A.; Windle, A.H. Direct Spinning of Carbon Nanotube Fibers from Chemical Vapor Deposition Synthesis. Science 2004, 304, 276-278. [CrossRef]

70. Janas, D.; Milowska, K.Z.; Bristowe, P.D.; Koziol, K.K. Improving the Electrical Properties of Carbon Nanotubes with Interhalogen Compounds. Nanoscale 2017, 9, 3212-3221. [CrossRef] [PubMed]

71. Lepak-Kuc, S.; Milowska, K.Z.; Boncel, S.; Szybowicz, M.; Dychalska, A.; Jozwik, I.; Koziol, K.K.; Jakubowska, M.; Lekawa-Raus, A. Highly Conductive Doped Hybrid Carbon Nanotube-Graphene Wires. ACS Appl. Mater. Interfaces 2019, 11, 33207-33220. [CrossRef]

72. Tran, T.Q.; Fan, Z.; Liu, P.; Myint, S.M.; Duong, H.M. Super-Strong and Highly Conductive Carbon Nanotube Ribbons from Post-Treatment Methods. Carbon 2016, 99, 407-415. [CrossRef]

73. Clancy, A.J.; White, E.R.; Tay, H.H.; Yau, H.C.; Shaffer, M.S.P. Systematic Comparison of Conventional and Reductive SingleWalled Carbon Nanotube Purifications. Carbon 2016, 108, 423-432. [CrossRef]

74. Hansson, J.; Nylander, A.; Flygare, M.; Svensson, K.; Ye, L.; Nilsson, T.; Fu, Y.; Liu, J. Effects of High Temperature Treatment of Carbon Nanotube Arrays on Graphite: Increased Crystallinity, Anchoring and Inter-Tube Bonding. Nanotechnology 2020, 31, 455708. [CrossRef] [PubMed]

75. Mattia, D.; Rossi, M.P.; Kim, B.M.; Korneva, G.; Bau, H.H.; Gogotsi, Y. Effect of Graphitization on the Wettability and Electrical Conductivity of CVD-Carbon Nanotubes and Films. J. Phys. Chem. B 2006, 110, 9850-9855. [CrossRef] [PubMed]

76. Janas, D. Towards Monochiral Carbon Nanotubes: A Review of Progress in the Sorting of Single-Walled Carbon Nanotubes. Mater. Chem. Front. 2018, 2, 36-63. [CrossRef]

77. Fagan, J.A. Aqueous Two-Polymer Phase Extraction of Single-Wall Carbon Nanotubes Using Surfactants. Nanoscale Adv. 2019, 1,3307-3324. [CrossRef]

78. Janas, D.; Koziol, K.K. Rapid Electrothermal Response of High-Temperature Carbon Nanotube Film Heaters. Carbon 2013, 59, 457-463. [CrossRef]

79. Hou, G.; Wang, G.; Deng, Y.; Zhang, J.; Nshimiyimana, J.P.; Chi, X.; Hu, X.; Chu, W.; Dong, H.; Zhang, Z.; et al. Effective Enhancement of the Mechanical Properties of Macroscopic Single-Walled Carbon Nanotube Fibers by Pressure Treatment. RSC Adv. 2016, 6, 97012-97017. [CrossRef]

80. Wang, J.N.; Luo, X.G.; Wu, T.; Chen, Y. High-Strength Carbon Nanotube Fibre-like Ribbon with High Ductility and High Electrical Conductivity. Nat. Commun. 2014, 5, 3848. [CrossRef] [PubMed] 
81. Liu, P.; Tan, Y.F.; Hu, D.C.M.; Jewell, D.; Duong, H.M. Multi-Property Enhancement of Aligned Carbon Nanotube Thin Films from Floating Catalyst Method. Mater. Des. 2016, 108, 754-760. [CrossRef]

82. Han, B.; Xue, X.; Xu, Y.; Zhao, Z.; Guo, E.; Liu, C.; Luo, L.; Hou, H. Preparation of Carbon Nanotube Film with High Alignment and Elevated Density. Carbon 2017, 122, 496-503. [CrossRef]

83. Zhou, W.; Vavro, J.; Nemes, N.M.; Fischer, J.E.; Borondics, F.; Kamaras, K.; Tanner, D. Charge Transfer and Fermi Level Shift in P-Doped Single-Walled Carbon Nanotubes. Phys. Rev. B 2005, 71, 205423. [CrossRef]

84. Kamarás, K.; Pekker, Á.; Botka, B.; Hu, H.; Niyogi, S.; Itkis, M.E.; Haddon, R.C. The Effect of Nitric Acid Doping on the Optical Properties of Carbon Nanotube Films. Phys. Status Solidi (B) 2010, 247, 2754-2757. [CrossRef]

85. Zhao, Y.; Wei, J.; Vajtai, R.; Ajayan, P.M.; Barrera, E.V. Iodine Doped Carbon Nanotube Cables Exceeding Specific Electrical Conductivity of Metals. Sci. Rep. 2011, 1, 83. [CrossRef] [PubMed]

86. Lee, R.S.; Kim, H.J.; Fischer, J.E.; Thess, A.; Smalley, R.E. Conductivity Enhancement in Single-Walled Carbon Nanotube Bundles Doped with K and Br. Nature 1997, 388, 255-257. [CrossRef]

87. Schmid, M.; Goze-Bac, C.; Krämer, S.; Roth, S.; Mehring, M.; Mathis, C.; Petit, P. Metallic Properties of Li-Intercalated Carbon Nanotubes Investigated by NMR. Phys. Rev. B 2006, 74, 073416. [CrossRef]

88. Klinke, C.; Chen, J.; Afzali, A.; Avouris, P. Charge Transfer Induced Polarity Switching in Carbon Nanotube Transistors. Nano Lett. 2005, 5, 555-558. [CrossRef] [PubMed]

89. Ayala, P.; Arenal, R.; Rümmeli, M.; Rubio, A.; Pichler, T. The Doping of Carbon Nanotubes with Nitrogen and Their Potential Applications. Carbon 2010, 48, 575-586. [CrossRef]

90. Janas, D.; Herman, A.P.; Boncel, S.; Koziol, K.K.K. Iodine Monochloride as a Powerful Enhancer of Electrical Conductivity of Carbon Nanotube Wires. Carbon 2014, 73, 225-233. [CrossRef]

91. Wang, X.; Behabtu, N.; Young, C.C.; Tsentalovich, D.E.; Pasquali, M.; Kono, J. High-Ampacity Power Cables of Tightly-Packed and Aligned Carbon Nanotubes. Adv. Funct. Mater. 2014, 24, 3241-3249. [CrossRef]

92. Mokry, G.; Pozuelo, J.; Vilatela, J.J.; Sanz, J.; Baselga, J. High Ampacity Carbon Nanotube Materials. Nanomaterials 2019, 9 , 383. [CrossRef]

93. Subramaniam, C.; Yamada, T.; Kobashi, K.; Sekiguchi, A.; Futaba, D.N.; Yumura, M.; Hata, K. One Hundred Fold Increase in Current Carrying Capacity in a Carbon Nanotube-Copper Composite. Nat. Commun. 2013, 4, 2202. [CrossRef]

94. Hong, S.; Myung, S. A Flexible Approach to Mobility. Nat. Nanotechnol. 2007, 2, 207-208. [CrossRef]

95. Park, J.G.; Li, S.; Liang, R.; Fan, X.; Zhang, C.; Wang, B. The High Current-Carrying Capacity of Various Carbon Nanotube-Based Buckypapers. Nanotechnology 2008, 19, 185710. [CrossRef] [PubMed]

96. Whittaker, A.G. The Controversial Carbon Solid-Liquid-Vapour Triple Point. Nature 1978, 276, 695-696. [CrossRef]

97. Cahill, J.A.; Kirshenbaum, A.D. The Density of liquid copper from its melting point $\left(1356^{\circ} \mathrm{k}\right.$.) to $2500^{\circ} \mathrm{k}$. and an estimate of its critical constants1,2. J. Phys. Chem. 1962, 66, 1080-1082. [CrossRef]

98. Li, C.; Liu, M.; Ding, H.; He, L.; Wang, E.; Wang, B.; Fan, S.; Liu, K. A Lightly Fe-Doped (NiS2/MoS2)/Carbon Nanotube Hybrid Electrocatalyst Film with Laser-Drilled Micropores for Stabilized Overall Water Splitting and PH-Universal Hydrogen Evolution Reaction. J. Mater. Chem. A 2020, 8, 17527-17536. [CrossRef]

99. Reuillard, B.; Warnan, J.; Leung, J.J.; Wakerley, D.W.; Reisner, E. A Poly(Cobaloxime)/Carbon Nanotube Electrode: Freestanding Buckypaper with Polymer-Enhanced H2-Evolution Performance. Angew. Chem. Int. Ed. 2016, 55, 3952-3957. [CrossRef] [PubMed]

100. Tang, J.M.; Jensen, K.; Waje, M.; Li, W.; Larsen, P.; Pauley, K.; Chen, Z.; Ramesh, P.; Itkis, M.E.; Yan, Y.; et al. High Performance Hydrogen Fuel Cells with Ultralow Pt Loading Carbon Nanotube Thin Film Catalysts. J. Phys. Chem. C 2007, 111, 17901-17904. [CrossRef]

101. Sai Siddhardha, R.S.; Lakshminarayanan, V.; Ramamurthy, S.S. Spot-Free Catalysis Using Gold Carbon Nanotube \& Gold Graphene Composites for Hydrogen Evolution Reaction. J. Power Sources 2015, 288, 441-450. [CrossRef]

102. Wang, T.; Li, X.; Jiang, Y.; Zhou, Y.; Jia, L.; Wang, C. Reduced Graphene Oxide-Polyimide/Carbon Nanotube Film Decorated with NiSe Nanoparticles for Electrocatalytic Hydrogen Evolution Reactions. Electrochim. Acta 2017, 243, 291-298. [CrossRef]

103. Cui, W.; Liu, Q.; Cheng, N.; Asiri, A.M.; Sun, X. Activated Carbon Nanotubes: A Highly-Active Metal-Free Electrocatalyst for Hydrogen Evolution Reaction. Chem. Commun. 2014, 50, 9340-9342. [CrossRef]

104. Wang, L.; Pumera, M. Residual Metallic Impurities within Carbon Nanotubes Play a Dominant Role in Supposedly "Metal-Free" Oxygen Reduction Reactions. Chem. Commun. 2014, 50, 12662-12664. [CrossRef] [PubMed]

105. Nikitin, A.; Ogasawara, H.; Mann, D.; Denecke, R.; Zhang, Z.; Dai, H.; Cho, K.; Nilsson, A. Hydrogenation of Single-Walled Carbon Nanotubes. Phys. Rev. Lett. 2005, 95, 225507. [CrossRef] [PubMed]

106. Pumera, M. Voltammetry of Carbon Nanotubes and Graphenes: Excitement, Disappointment, and Reality. Chem. Rec. 2012, 12, 201-213. [CrossRef]

107. Wang; Shan, H.; Hauge, R.H.; Pasquali, M.; Smalley, R.E. A Highly Selective, One-Pot Purification Method for Single-Walled Carbon Nanotubes. J. Phys. Chem. B 2007, 111, 1249-1252. [CrossRef] [PubMed]

108. Liu, X.; Guo, L.; Morris, D.; Kane, A.B.; Hurt, R.H. Targeted Removal of Bioavailable Metal as a Detoxification Strategy for Carbon Nanotubes. Carbon 2008, 46, 489-500. [CrossRef] [PubMed]

109. Pumera, M. Carbon Nanotubes Contain Residual Metal Catalyst Nanoparticles Even after Washing with Nitric Acid at Elevated Temperature Because These Metal Nanoparticles Are Sheathed by Several Graphene Sheets. Langmuir 2007, 23, 6453-6458. [CrossRef] [PubMed] 
110. Deng, D.; Yu, L.; Chen, X.; Wang, G.; Jin, L.; Pan, X.; Deng, J.; Sun, G.; Bao, X. Iron Encapsulated within Pod-like Carbon Nanotubes for Oxygen Reduction Reaction. Angew. Chem. Int. Ed. 2013, 52, 371-375. [CrossRef] [PubMed]

111. Vazquez-Arenas, J.; Higgins, D.; Chen, Z.; Fowler, M.; Chen, Z. Mechanistic Analysis of Highly Active Nitrogen-Doped Carbon Nanotubes for the Oxygen Reduction Reaction. J. Power Sources 2012, 205, 215-221. [CrossRef]

112. Wang, X.; Ouyang, C.; Dou, S.; Liu, D.; Wang, S. Oxidized Carbon Nanotubes as an Efficient Metal-Free Electrocatalyst for the Oxygen Reduction Reaction. RSC Adv. 2015, 5, 41901-41904. [CrossRef]

113. Lee, W.J.; Maiti, U.N.; Lee, J.M.; Lim, J.; Han, T.H.; Kim, S.O. Nitrogen-Doped Carbon Nanotubes and Graphene Composite Structures for Energy and Catalytic Applications. Chem. Commun. 2014, 50, 6818-6830. [CrossRef] [PubMed]

114. Yen, C.H.; Shimizu, K.; Lin, Y.-Y.; Bailey, F.; Cheng, I.F.; Wai, C.M. Chemical Fluid Deposition of Pt-Based Bimetallic Nanoparticles on Multiwalled Carbon Nanotubes for Direct Methanol Fuel Cell Application. Energy Fuels 2007, 21, 2268-2271. [CrossRef]

115. Jeng, K.-T.; Chien, C.-C.; Hsu, N.-Y.; Yen, S.-C.; Chiou, S.-D.; Lin, S.-H.; Huang, W.-M. Performance of Direct Methanol Fuel Cell Using Carbon Nanotube-Supported Pt-Ru Anode Catalyst with Controlled Composition. J. Power Sources 2006, 160, 97-104. [CrossRef]

116. Ramli, Z.A.C.; Kamarudin, S.K. Platinum-Based Catalysts on Various Carbon Supports and Conducting Polymers for Direct Methanol Fuel Cell Applications: A Review. Nanoscale Res. Lett. 2018, 13, 410. [CrossRef]

117. Rohland, B.; Pietrzak, M.; Möller, S.; Bunescu, M.-C.; Wienecke, M.; Barfels, T. CNT-Based Cathode Material for DMFC. Fuller. Nanotub. Carbon Nanostruct. 2005, 13, 511-522. [CrossRef]

118. Li, X.; Zhang, J.; Qi, G.; Cheng, J.; Wang, B. Vertically Aligned N-Doped Carbon Nanotubes Arrays as Efficient Binder-Free Catalysts for Flexible Li-CO 2 Batteries. Energy Storage Mater. 2021, 35, 148-156. [CrossRef]

119. Jiménez, C.; García, J.; Camarillo, R.; Martínez, F.; Rincón, J. Electrochemical $\mathrm{CO}_{2}$ Reduction to Fuels Using Pt/CNT Catalysts Synthesized in Supercritical Medium. Energy Fuels 2017, 31, 3038-3046. [CrossRef]

120. Safdar Hossain, S.; Rahman, S.; Ahmed, S. Electrochemical Reduction of Carbon Dioxide over CNT-Supported Nanoscale Copper Electrocatalysts. J. Nanomater. 2014, 2014, 374318. [CrossRef]

121. Hjorth, I.; Nord, M.; Rønning, M.; Yang, J.; Chen, D. Electrochemical Reduction of $\mathrm{CO}_{2}$ to Synthesis Gas on CNT Supported CuxZn1-x O Catalysts. Catal. Today 2020, 357, 311-321. [CrossRef]

122. Zhang, X.; Wu, Z.; Zhang, X.; Li, L.; Li, Y.; Xu, H.; Li, X.; Yu, X.; Zhang, Z.; Liang, Y.; et al. Highly Selective and Active CO 2 Reduction Electrocatalysts Based on Cobalt Phthalocyanine/Carbon Nanotube Hybrid Structures. Nat. Commun. 2017, $8,14675$. [CrossRef]

123. Krukiewicz, K.; Janas, D.; Vallejo-Giraldo, C.; Biggs, M.J.P. Self-Supporting Carbon Nanotube Films as Flexible Neural Interfaces. Electrochim. Acta 2019, 295, 253-261. [CrossRef]

124. Gerwig, R.; Fuchsberger, K.; Schroeppel, B.; Link, G.; Heusel, G.; Kraushaar, U.; Schuhmann, W.; Stett, A.; Stelzle, M. PEDOTCNT Composite Microelectrodes for Recording and Electrostimulation Applications: Fabrication, Morphology, and Electrical Properties. Front. Neuroeng. 2012, 5, 8. [CrossRef]

125. Mata, D.; Oliveira, F.J.; Neto, M.A.; Belmonte, M.; Bastos, A.C.; Lopes, M.A.; Gomes, P.S.; Fernandes, M.H.; Silva, R.F. Smart Electroconductive Bioactive Ceramics to Promote in Situ Electrostimulation of Bone. J. Mater. Chem. B 2015, 3, 1831-1845. [CrossRef]

126. Eleftheriou, C.G.; Zimmermann, J.B.; Kjeldsen, H.D.; David-Pur, M.; Hanein, Y.; Sernagor, E. Carbon Nanotube Electrodes for Retinal Implants: A Study of Structural and Functional Integration over Time. Biomaterials 2017, 112, 108-121. [CrossRef]

127. Samba, R.; Herrmann, T.; Zeck, G. PEDOT-CNT Coated Electrodes Stimulate Retinal Neurons at Low Voltage Amplitudes and Low Charge Densities. J. Neural Eng. 2015, 12, 016014. [CrossRef] [PubMed]

128. Wei, H.; Liu, Y.; Zhai, X.; Wang, F.; Ren, X.; Tao, F.; Li, T.; Wang, G.; Ren, F. Application of Carbon Nanotube-Based Materials as Interlayers in High-Performance Lithium-Sulfur Batteries: A Review. Front. Energy Res. 2020, 8. [CrossRef]

129. Li, L.; Yang, H.; Zhou, D.; Zhou, Y. Progress in Application of CNTs in Lithium-Ion Batteries. Available online: https://www. hindawi.com/journals/jnm/2014/187891/ (accessed on 8 February 2021).

130. Chew, S.Y.; Ng, S.H.; Wang, J.; Novák, P.; Krumeich, F.; Chou, S.L.; Chen, J.; Liu, H.K. Flexible Free-Standing Carbon Nanotube Films for Model Lithium-Ion Batteries. Carbon 2009, 47, 2976-2983. [CrossRef]

131. Yoon, S.; Lee, S.; Kim, S.; Park, K.-W.; Cho, D.; Jeong, Y. Carbon Nanotube Film Anodes for Flexible Lithium Ion Batteries. J. Power Sources 2015, 279, 495-501. [CrossRef]

132. Schulze, M.C.; Belson, R.M.; Kraynak, L.A.; Prieto, A.L. Electrodeposition of Sb/CNT Composite Films as Anodes for Li- and Na-Ion Batteries. Energy Storage Mater. 2020, 25, 572-584. [CrossRef]

133. Cao, Z.; Wei, B.B.Q. A Perspective: Carbon Nanotube Macro-Films for Energy Storage. Energy Environ. Sci. 2013, 6, 3183-3201. [CrossRef]

134. Yu, D.; Dai, L. Self-Assembled Graphene/Carbon Nanotube Hybrid Films for Supercapacitors. J. Phys. Chem. Lett. 2010, 1, 467-470. [CrossRef]

135. Ciszewski, M.; Koszorek, A.; Radko, T.; Szatkowski, P.; Janas, D. Review of the Selected Carbon-Based Materials for Symmetric Supercapacitor Application. J. Electron. Mater. 2019, 48, 717-744. [CrossRef]

136. Díez, N.; Botas, C.; Mysyk, R.; Goikolea, E.; Rojo, T.; Carriazo, D. Highly Packed Graphene-CNT Films as Electrodes for Aqueous Supercapacitors with High Volumetric Performance. J. Mater. Chem. A 2018, 6, 3667-3673. [CrossRef]

137. Lu, W.; Dai, L. Carbon Nanotube Supercapacitors. Carbon Nanotub. 2010. [CrossRef] 
138. Aval, L.F.; Ghoranneviss, M.; Pour, G.B. High-Performance Supercapacitors Based on the Carbon Nanotubes, Graphene and Graphite Nanoparticles Electrodes. Heliyon 2018, 4, e00862. [CrossRef]

139. Yu, Y.; Luo, Y.; Wu, H.; Jiang, K.; Li, Q.; Fan, S.; Li, J.; Wang, J. Ultrastretchable Carbon Nanotube Composite Electrodes for Flexible Lithium-Ion Batteries. Nanoscale 2018, 10, 19972-19978. [CrossRef] [PubMed]

140. Frackowiak, E.; Béguin, F. Carbon Materials for the Electrochemical Storage of Energy in Capacitors. Carbon 2001, 39, 937-950. [CrossRef]

141. Notarianni, M.; Liu, J.; Mirri, F.; Pasquali, M.; Motta, N. Graphene-Based Supercapacitor with Carbon Nanotube Film as Highly Efficient Current Collector. Nanotechnology 2014, 25, 435405. [CrossRef]

142. Tiwari, P.; Janas, D.; Chandra, R. Ultrahigh Rate Supercapacitor Based on Self-Standing Carbon Nanotubes Supported Vertically Aligned MoS2 Sheets. MRS Adv. 2020, 5, 2495-2502. [CrossRef]

143. Joseph, N.; Shafi, P.M.; Bose, A.C. Recent Advances in 2D-MoS2 and Its Composite Nanostructures for Supercapacitor Electrode Application. Energy Fuels 2020, 34, 6558-6597. [CrossRef]

144. Das, C.M.; Kang, L.; Ouyang, Q.; Yong, K.-T. Advanced Low-Dimensional Carbon Materials for Flexible Devices. InfoMat 2020, 2, 698-714. [CrossRef]

145. Pan, Z.; Liu, M.; Yang, J.; Qiu, Y.; Li, W.; Xu, Y.; Zhang, X.; Zhang, Y. High Electroactive Material Loading on a Carbon Nanotube@3D Graphene Aerogel for High-Performance Flexible All-Solid-State Asymmetric Supercapacitors. Adv. Funct. Mater. 2017, 27, 1701122. [CrossRef]

146. Tiwari, P.; Janas, D.; Chandra, R. Self-Standing MoS2/CNT and MnO2/CNT One Dimensional Core Shell Heterostructures for Asymmetric Supercapacitor Application. Carbon 2021, 177, 291-303. [CrossRef]

147. Hao, M.; Huang, Z.; Saviers, K.R.; Xiong, G.; Hodson, S.L.; Fisher, T.S. Characterization of Vertically Oriented Carbon Nanotube Arrays as High-Temperature Thermal Interface Materials. Int. J. Heat Mass Transf. 2017, 106, 1287-1293. [CrossRef]

148. Qiu, L.; Scheider, K.; Radwan, S.A.; Larkin, L.S.; Saltonstall, C.B.; Feng, Y.; Zhang, X.; Norris, P.M. Thermal Transport Barrier in Carbon Nanotube Array Nano-Thermal Interface Materials. Carbon 2017, 120, 128-136. [CrossRef]

149. Taphouse, J.H.; Bougher, T.L.; Singh, V.; Abadi, P.P.S.S.; Graham, S.; Cola, B.A. Carbon Nanotube Thermal Interfaces Enhanced with Sprayed on Nanoscale Polymer Coatings. Nanotechnology 2013, 24, 105401. [CrossRef]

150. Qiu, L.; Guo, P.; Kong, Q.; Tan, C.W.; Liang, K.; Wei, J.; Tey, J.N.; Feng, Y.; Zhang, X.; Tay, B.K. Coating-Boosted Interfacial Thermal Transport for Carbon Nanotube Array Nano-Thermal Interface Materials. Carbon 2019, 145, 725-733. [CrossRef]

151. Liu, X.; Zhang, Y.; Cassell, A.M.; Cruden, B.A. Implications of Catalyst Control for Carbon Nanotube Based Thermal Interface Materials. J. Appl. Phys. 2008, 104, 084310. [CrossRef]

152. Xu, Y.; Zhang, Y.; Suhir, E.; Wang, X. Thermal Properties of Carbon Nanotube Array Used for Integrated Circuit Cooling. J. Appl. Phys. 2006, 100, 074302. [CrossRef]

153. Cola, B.A.; Amama, P.B.; Xu, X.; Fisher, T.S. Effects of Growth Temperature on Carbon Nanotube Array Thermal Interfaces. J. Heat Transf. 2008, 130. [CrossRef]

154. Amama, P.B.; Cola, B.A.; Sands, T.D.; Xu, X.; Fisher, T.S. Dendrimer-Assisted Controlled Growth of Carbon Nanotubes for Enhanced Thermal Interface Conductance. Nanotechnology 2007, 18, 385303. [CrossRef]

155. Cross, R.; Cola, B.A.; Fisher, T.; Xu, X.; Gall, K.; Graham, S. A Metallization and Bonding Approach for High Performance Carbon Nanotube Thermal Interface Materials. Nanotechnology 2010, 21, 445705. [CrossRef] [PubMed]

156. Kong, Q.; Bodelot, L.; Lebental, B.; Lim, Y.D.; Shiau, L.L.; Gusarov, B.; Tan, C.W.; Liang, K.; Lu, C.; Tan, C.S.; et al. Novel Three-Dimensional Carbon Nanotube Networks as High Performance Thermal Interface Materials. Carbon 2018, 132, 359-369. [CrossRef]

157. Jun, X.; Fisher, T.S. Enhanced Thermal Contact Conductance Using Carbon Nanotube Array Interfaces. IEEE Trans. Compon. Packag. Technol. 2006, 29, 261-267. [CrossRef]

158. Qiu, L.; Wang, X.; Su, G.; Tang, D.; Zheng, X.; Zhu, J.; Wang, Z.; Norris, P.M.; Bradford, P.D.; Zhu, Y. Remarkably Enhanced Thermal Transport Based on a Flexible Horizontally-Aligned Carbon Nanotube Array Film. Sci. Rep. 2016, 6, 21014. [CrossRef] [PubMed]

159. Chen, H.; Chen, M.; Di, J.; Xu, G.; Li, H.; Li, Q. Architecting Three-Dimensional Networks in Carbon Nanotube Buckypapers for Thermal Interface Materials. J. Phys. Chem. C 2012, 116, 3903-3909. [CrossRef]

160. Blackburn, J.L.; Ferguson, A.J.; Cho, C.; Grunlan, J.C. Carbon-Nanotube-Based Thermoelectric Materials and Devices. Adv. Mater. 2018, 30, 1704386. [CrossRef] [PubMed]

161. Hung, N.T.; Nugraha, A.R.T.; Hasdeo, E.H.; Dresselhaus, M.S.; Saito, R. Diameter Dependence of Thermoelectric Power of Semiconducting Carbon Nanotubes. Phys. Rev. B 2015, 92, 165426. [CrossRef]

162. Piao, M.; Joo, M.-K.; Na, J.; Kim, Y.-J.; Mouis, M.; Ghibaudo, G.; Roth, S.; Kim, W.-Y.; Jang, H.-K.; Kennedy, G.P.; et al. Effect of Intertube Junctions on the Thermoelectric Power of Monodispersed Single Walled Carbon Nanotube Networks. J. Phys. Chem. C 2014, 118, 26454-26461. [CrossRef]

163. Lian, F.; Llinas, J.P.; Li, Z.; Estrada, D.; Pop, E. Thermal Conductivity of Chirality-Sorted Carbon Nanotube Networks. Appl. Phys. Lett. 2016, 108, 103101. [CrossRef]

164. Nonoguchi, Y.; Ohashi, K.; Kanazawa, R.; Ashiba, K.; Hata, K.; Nakagawa, T.; Adachi, C.; Tanase, T.; Kawai, T. Systematic Conversion of Single Walled Carbon Nanotubes into N-Type Thermoelectric Materials by Molecular Dopants. Sci. Rep. 2013, 3, 3344. [CrossRef] 
165. Nakai, Y.; Honda, K.; Yanagi, K.; Kataura, H.; Kato, T.; Yamamoto, T.; Maniwa, Y. Giant Seebeck Coefficient in Semiconducting Single-Wall Carbon Nanotube Film. Appl. Phys. Express 2014, 7, 025103. [CrossRef]

166. Hone, J.; Ellwood, I.; Muno, M.; Mizel, A.; Cohen, M.L.; Zettl, A.; Rinzler, A.G.; Smalley, R.E. Thermoelectric Power of Single-Walled Carbon Nanotubes. Phys. Rev. Lett. 1998, 80, 1042-1045. [CrossRef]

167. Jia, S.-L.; Geng, H.-Z.; Wang, L.; Tian, Y.; Xu, C.-X.; Shi, P.-P.; Gu, Z.-Z.; Yuan, X.-S.; Jing, L.-C.; Guo, Z.-Y.; et al. Carbon Nanotube-Based Flexible Electrothermal Film Heaters with a High Heating Rate. R. Soc. Open Sci. 2018, 5, 172072. [CrossRef]

168. Park, J.; Jang, I.R.; Lee, K.; Kim, H.J. High Efficiency Crumpled Carbon Nanotube Heaters for Low Drift Hydrogen Sensing. Sensors 2019, 19, 3878. [CrossRef]

169. Ning, W.; Wang, Z.; Liu, P.; Zhou, D.; Yang, S.; Wang, J.; Li, Q.; Fan, S.; Jiang, K. Multifunctional Super-Aligned Carbon Nanotube/Polyimide Composite Film Heaters and Actuators. Carbon 2018, 139, 1136-1143. [CrossRef]

170. Jung, D.; Kim, D.; Lee, K.H.; Overzet, L.J.; Lee, G.S. Transparent Film Heaters Using Multi-Walled Carbon Nanotube Sheets. Sens. Actuators A Phys. 2013, 199, 176-180. [CrossRef]

171. Fischer, T.; Rühling, J.; Wetzold, N.; Zillger, T.; Weissbach, T.; Göschel, T.; Würfel, M.; Hübler, A.; Kroll, L. Roll-to-Roll Printed Carbon Nanotubes on Textile Substrates as a Heating Layer in Fiber-Reinforced Epoxy Composites. J. Appl. Polym. Sci. 2018, 135, 45950. [CrossRef]

172. Li, Y.; Zhang, Z.; Li, X.; Zhang, J.; Lou, H.; Shi, X.; Cheng, X.; Peng, H. A Smart, Stretchable Resistive Heater Textile. J. Mater. Chem. C 2016, 5, 41-46. [CrossRef]

173. Luo, J.; Lu, H.; Zhang, Q.; Yao, Y.; Chen, M.; Li, Q. Flexible Carbon Nanotube/Polyurethane Electrothermal Films. Carbon 2016, 110, 343-349. [CrossRef]

174. Liang, B.; Zhang, Z.; Chen, W.; Lu, D.; Yang, L.; Yang, R.; Zhu, H.; Tang, Z.; Gui, X. Direct Patterning of Carbon Nanotube via Stamp Contact Printing Process for Stretchable and Sensitive Sensing Devices. Nano-Micro Lett. 2019, 11, 92. [CrossRef]

175. Chang-Jian, S.-K.; Ho, J.-R. Laser Patterning of Carbon-Nanotubes Thin Films and Their Applications. Carbon Nanotub. Appl. Electron. Devices 2011. [CrossRef]

176. Dong, L.; Youkey, S.; Bush, J.; Jiao, J.; Dubin, V.M.; Chebiam, R.V. Effects of Local Joule Heating on the Reduction of Contact Resistance between Carbon Nanotubes and Metal Electrodes. J. Appl. Phys. 2007, 101, 024320. [CrossRef]

177. Costa, P.M.F.J.; Gautam, U.K.; Bando, Y.; Golberg, D. Direct Imaging of Joule Heating Dynamics and Temperature Profiling inside a Carbon Nanotube Interconnect. Nat. Commun. 2011, 2, 421. [CrossRef]

178. Santini, C.A.; Vereecken, P.M.; Volodin, A.; Groeseneken, G.; Gendt, S.D.; Haesendonck, C.V. A Study of Joule Heating-Induced Breakdown of Carbon Nanotube Interconnects. Nanotechnology 2011, 22, 395202. [CrossRef]

179. Collins, P.G.; Arnold, M.S.; Avouris, P. Engineering Carbon Nanotubes and Nanotube Circuits Using Electrical Breakdown. Science 2001, 292, 706-709. [CrossRef] [PubMed]

180. Collins, P.G.; Hersam, M.; Arnold, M.; Martel, R.; Avouris, P. Current Saturation and Electrical Breakdown in Multiwalled Carbon Nanotubes. Phys. Rev. Lett. 2001, 86, 3128-3131. [CrossRef]

181. Otsuka, K.; Inoue, T.; Chiashi, S.; Maruyama, S. Selective Removal of Metallic Single-Walled Carbon Nanotubes in Full Length by Organic Film-Assisted Electrical Breakdown. Nanoscale 2014, 6, 8831-8835. [CrossRef] [PubMed]

182. Yao, X.; Hawkins, S.C.; Falzon, B.G. An Advanced Anti-Icing/de-Icing System Utilizing Highly Aligned Carbon Nanotube Webs. Carbon 2018, 136, 130-138. [CrossRef]

183. Kataura, H.; Kumazawa, Y.; Maniwa, Y.; Umezu, I.; Suzuki, S.; Ohtsuka, Y.; Achiba, Y. Optical Properties of Single-Wall Carbon Nanotubes. Synth. Met. 1999, 103, 2555-2558. [CrossRef]

184. Soetedjo, H.; Mora, M.F.; Garcia, C.D. Optical Properties of Single-Wall Carbon Nanotube Films Deposited on $\mathrm{Si}_{/} \mathrm{SiO}_{2} \mathrm{Wafers}$. Thin Solid Film. 2010, 518, 3954-3959. [CrossRef] [PubMed]

185. Wieland, L.; Li, H.; Rust, C.; Chen, J.; Flavel, B.S. Carbon Nanotubes for Photovoltaics: From Lab to Industry. Adv. Energy Mater. 2021, 11, 2002880. [CrossRef]

186. Contreras, M.A.; Barnes, T.; van de Lagemaat, J.; Rumbles, G.; Coutts, T.J.; Weeks, C.; Glatkowski, P.; Levitsky, I.; Peltola, J.; Britz, D.A. Replacement of Transparent Conductive Oxides by Single-Wall Carbon Nanotubes in $\mathrm{Cu}(\mathrm{In}, \mathrm{Ga}) \mathrm{Se}_{2}$-Based Solar Cells. J. Phys. Chem. C 2007, 111, 14045-14048. [CrossRef]

187. Aitola, K.; Domanski, K.; Correa-Baena, J.-P.; Sveinbjörnsson, K.; Saliba, M.; Abate, A.; Grätzel, M.; Kauppinen, E.; Johansson, E.M.J.; Tress, W.; et al. High Temperature-Stable Perovskite Solar Cell Based on Low-Cost Carbon Nanotube Hole Contact. Adv. Mater. 2017, 29, 1606398. [CrossRef] [PubMed]

188. Habisreutinger, S.N.; Leijtens, T.; Eperon, G.E.; Stranks, S.D.; Nicholas, R.J.; Snaith, H.J. Carbon Nanotube/Polymer Composites as a Highly Stable Hole Collection Layer in Perovskite Solar Cells. Nano Lett. 2014, 14, 5561-5568. [CrossRef]

189. Jeon, I.; Shawky, A.; Seo, S.; Qian, Y.; Anisimov, A.; Kauppinen, E.I.; Matsuo, Y.; Maruyama, S. Carbon Nanotubes to Outperform Metal Electrodes in Perovskite Solar Cells via Dopant Engineering and Hole-Selectivity Enhancement. J. Mater. Chem. A 2020, 8, 11141-11147. [CrossRef]

190. Bati, A.S.R.; Yu, L.; Batmunkh, M.; Shapter, J.G. Recent Advances in Applications of Sorted Single-Walled Carbon Nanotubes. Adv. Funct. Mater. 2019, 29, 1902273. [CrossRef]

191. Isborn, C.M.; Tang, C.; Martini, A.; Johnson, E.R.; Otero-de-la-Roza, A.; Tung, V.C. Carbon Nanotube Chirality Determines Efficiency of Electron Transfer to Fullerene in All-Carbon Photovoltaics. J. Phys. Chem. Lett. 2013, 4, 2914-2918. [CrossRef] 
192. Kolanowska, A.; Janas, D.; Herman, A.P.; Jędrysiak, R.G.; Giżewski, T.; Boncel, S. From Blackness to Invisibility-Carbon Nanotubes Role in the Attenuation of and Shielding from Radio Waves for Stealth Technology. Carbon 2018, 126, 31-52. [CrossRef]

193. Al-Saleh, M.H.; Saadeh, W.H.; Sundararaj, U. EMI Shielding Effectiveness of Carbon Based Nanostructured Polymeric Materials: A Comparative Study. Carbon 2013, 60, 146-156. [CrossRef]

194. Cui, K.; Wardle, B.L. Breakdown of Native Oxide Enables Multifunctional, Free-Form Carbon Nanotube-Metal Hierarchical Architectures. ACS Appl. Mater. Interfaces 2019, 11, 35212-35220. [CrossRef]

195. Sankaran, S.; Deshmukh, K.; Ahamed, M.B.; Khadheer Pasha, S.K. Recent Advances in Electromagnetic Interference Shielding Properties of Metal and Carbon Filler Reinforced Flexible Polymer Composites: A Review. Compos. Part A Appl. Sci. Manuf. 2018, 114, 49-71. [CrossRef]

196. Kim, H.M.; Kim, K.; Lee, S.J.; Joo, J.; Yoon, H.S.; Cho, S.J.; Lyu, S.C.; Lee, C.J. Charge Transport Properties of Composites of Multiwalled Carbon Nanotube with Metal Catalyst and Polymer: Application to Electromagnetic Interference Shielding. Curr. Appl. Phys. 2004, 4, 577-580. [CrossRef]

197. Yuen, S.-M.; Ma, C.-C.M.; Chuang, C.-Y.; Yu, K.-C.; Wu, S.-Y.; Yang, C.-C.; Wei, M.-H. Effect of Processing Method on the Shielding Effectiveness of Electromagnetic Interference of MWCNT/PMMA Composites. Compos. Sci. Technol. 2008, 68, 963-968. [CrossRef]

198. Chen, M.; Yin, X.; Li, M.; Chen, L.; Cheng, L.; Zhang, L. Electromagnetic Interference Shielding Properties of Silicon Nitride Ceramics Reinforced by in Situ Grown Carbon Nanotubes. Ceram. Int. 2015, 41, 2467-2475. [CrossRef]

199. Gupta, T.K.; Singh, B.P.; Dhakate, S.R.; Singh, V.N.; Mathur, R.B. Improved Nanoindentation and Microwave Shielding Properties of Modified MWCNT Reinforced Polyurethane Composites. J. Mater. Chem. A 2013, 1, 9138-9149. [CrossRef]

200. Singh, A.P.; Gupta, B.K.; Mishra, M.; Govind; Chandra, A.; Mathur, R.B.; Dhawan, S.K. Multiwalled Carbon Nanotube/Cement Composites with Exceptional Electromagnetic Interference Shielding Properties. Carbon 2013, 56, 86-96. [CrossRef]

201. Al-Saleh, M.H. Influence of Conductive Network Structure on the EMI Shielding and Electrical Percolation of Carbon Nanotube/Polymer Nanocomposites. Synth. Met. 2015, 205, 78-84. [CrossRef]

202. Verma, P.; Saini, P.; Malik, R.S.; Choudhary, V. Excellent Electromagnetic Interference Shielding and Mechanical Properties of High Loading Carbon-Nanotubes/Polymer Composites Designed Using Melt Recirculation Equipped Twin-Screw Extruder. Carbon 2015, 89, 308-317. [CrossRef]

203. Xiang, C.; Pan, Y.; Guo, J. Electromagnetic Interference Shielding Effectiveness of Multiwalled Carbon Nanotube Reinforced Fused Silica Composites. Ceram. Int. 2007, 33, 1293-1297. [CrossRef]

204. Zhang, C.-S.; Ni, Q.-Q.; Fu, S.-Y.; Kurashiki, K. Electromagnetic Interference Shielding Effect of Nanocomposites with Carbon Nanotube and Shape Memory Polymer. Compos. Sci. Technol. 2007, 67, 2973-2980. [CrossRef]

205. Chao, Z.; Yu, Y.; Lei, F.; Hu, D. A Lightweight and Flexible CNT/Fe3O4 Composite with High Electromagnetic Interference Shielding Performance. Carbon Lett. 2020. [CrossRef]

206. Zeng, S.; Li, X.; Li, M.; Zheng, J.; Shiju, E.; Yang, W.; Zhao, B.; Guo, X.; Zhang, R. Flexible PVDF/CNTs/Ni@CNTs Composite Films Possessing Excellent Electromagnetic Interference Shielding and Mechanical Properties under Heat Treatment. Carbon 2019, 155, 34-43. [CrossRef]

207. Wang, M.; Zhang, Y.; Dong, C.; Chen, G.; Guan, H. Preparation and Electromagnetic Shielding Effectiveness of Cobalt Ferrite Nanoparticles/Carbon Nanotubes Composites. Nanomater. Nanotechnol. 2019, 9, 1847980419837821. [CrossRef]

208. Feng, X.; Qin, X.; Liu, D.; Huang, Z.; Zhou, Y.; Lan, W.; Lu, F.; Qi, H. High Electromagnetic Interference Shielding Effectiveness of Carbon Nanotube-Cellulose Composite Films with Layered Structures. Macromol. Mater. Eng. 2018, 303, 1800377. [CrossRef]

209. Chikyu, N.; Nakano, T.; Kletetschka, G.; Inoue, Y. Excellent Electromagnetic Interference Shielding Characteristics of a Unidirectionally Oriented Thin Multiwalled Carbon Nanotube/Polyethylene Film. Mater. Des. 2020, 195, 108918. [CrossRef]

210. Wan, Y.-J.; Wang, X.-Y.; Li, X.-M.; Liao, S.-Y.; Lin, Z.-Q.; Hu, Y.-G.; Zhao, T.; Zeng, X.-L.; Li, C.-H.; Yu, S.-H.; et al. Ultrathin Densified Carbon Nanotube Film with "Metal-like" Conductivity, Superior Mechanical Strength, and Ultrahigh Electromagnetic Interference Shielding Effectiveness. ACS Nano 2020, 14, 14134-14145. [CrossRef]

211. Murakami, N.; Tango, Y.; Miyake, H.; Tajima, T.; Nishina, Y.; Kurashige, W.; Negishi, Y.; Takaguchi, Y. SWCNT Photocatalyst for Hydrogen Production from Water upon Photoexcitation of $(8,3)$ SWCNT at 680-Nm Light. Sci. Rep. 2017, 7, 43445. [CrossRef]

212. Izawa, T.; Kalousek, V.; Miyamoto, D.; Murakami, N.; Miyake, H.; Tajima, T.; Kurashige, W.; Negishi, Y.; Ikeue, K.; Ohkubo, T.; et al. Carbon-Nanotube-Based Photocatalysts for Water Splitting in Cooperation with $\mathrm{BiVO}_{4}$ and $\left[\mathrm{Co}(\mathrm{Bpy})_{3}\right]_{3}+/ 2_{2}+$. Chem. Lett. 2019, 48, 410-413. [CrossRef]

213. Murakami, N.; Miyake, H.; Tajima, T.; Nishikawa, K.; Hirayama, R.; Takaguchi, Y. Enhanced Photosensitized Hydrogen Production by Encapsulation of Ferrocenyl Dyes into Single-Walled Carbon Nanotubes. J. Am. Chem. Soc. 2018, 140, 3821-3824. [CrossRef] [PubMed]

214. Song, L.; Kang, X.; Zhang, S. CNT/g-C3N4 Photocatalysts with Enhanced Hydrogen Evolution Ability for Water Splitting Based on a Noncovalent Interaction. Int. J. Energy Res. 2018, 42, 1649-1656. [CrossRef]

215. Ye, A.; Fan, W.; Zhang, Q.; Deng, W.; Wang, Y. CdS-Graphene and CdS-CNT Nanocomposites as Visible-Light Photocatalysts for Hydrogen Evolution and Organic Dye Degradation. Catal. Sci. Technol. 2012, 2, 969-978. [CrossRef]

216. Dai, K.; Zhang, X.; Fan, K.; Zeng, P.; Peng, T. Multiwalled Carbon Nanotube-TiO2 Nanocomposite for Visible-Light-Induced Photocatalytic Hydrogen Evolution. J. Nanomater. 2014, 2014, 694073. [CrossRef]

217. Cao, S.; Yu, J. Carbon-Based H2-Production Photocatalytic Materials. J. Photochem. Photobiol. C Photochem. Rev. 2016, 27, 72-99. [CrossRef] 
218. Nakashima, N. Nanocarbons for Energy Conversion: Supramolecular Approaches; Springer: Berlin/Heidelberg, Germany, 2019; ISBN 3-319-92917-8.

219. Kubacka, A.; Fernández-García, M.; Colón, G. Advanced Nanoarchitectures for Solar Photocatalytic Applications. Chem. Rev. 2012, 112, 1555-1614. [CrossRef]

220. Kandy, M.M. Carbon-Based Photocatalysts for Enhanced Photocatalytic Reduction of $\mathrm{CO}_{2}$ to Solar Fuels. Sustain. Energy Fuels 2020, 4, 469-484. [CrossRef]

221. Rodríguez, V.; Camarillo, R.; Martínez, F.; Jiménez, C.; Rincón, J. $\mathrm{CO}_{2}$ Photocatalytic Reduction with $\mathrm{CNT}_{\text {TiO }}$ Based Nanocomposites Prepared by High-Pressure Technology. J. Supercrit. Fluids 2020, 163, 104876. [CrossRef]

222. Ong, W.-J.; Gui, M.M.; Chai, S.-P.; Mohamed, A.R. Direct Growth of Carbon Nanotubes on Ni/TiO2 as next Generation Catalysts for Photoreduction of $\mathrm{CO}_{2}$ to Methane by Water under Visible Light Irradiation. RSC Adv. 2013, 3, 4505-4509. [CrossRef]

223. Olowoyo, J.O.; Kumar, M.; Jain, S.L.; Babalola, J.O.; Vorontsov, A.V.; Kumar, U. Insights into Reinforced Photocatalytic Activity of the $\mathrm{CNT}-\mathrm{TiO}_{2}$ Nanocomposite for $\mathrm{CO}_{2}$ Reduction and Water Splitting. J. Phys. Chem. C 2019, 123, 367-378. [CrossRef]

224. Lashgari, M.; Soodi, S.; Zeinalkhani, P. Photocatalytic Back-Conversion of $\mathrm{CO}_{2}$ into Oxygenate Fuels Using an Efficient $\mathrm{ZnO} / \mathrm{CuO} /$ Carbon Nanotube Solar-Energy-Material: Artificial Photosynthesis. J. CO2 Util. 2017, 18, 89-97. [CrossRef]

225. Fang, Z.; Li, S.; Gong, Y.; Liao, W.; Tian, S.; Shan, C.; He, C. Comparison of Catalytic Activity of Carbon-Based AgBr Nanocomposites for Conversion of $\mathrm{CO}_{2}$ under Visible Light. J. Saudi Chem. Soc. 2014, 18, 299-307. [CrossRef]

226. Fu, Z.-C.; Xu, R.-C.; Moore, J.T.; Liang, F.; Nie, X.-C.; Mi, C.; Mo, J.; Xu, Y.; Xu, Q.-Q.; Yang, Z.; et al. Highly Efficient Photocatalytic System Constructed from CoP/Carbon Nanotubes or Graphene for Visible-Light-Driven $\mathrm{CO}_{2}$ Reduction. Chem. Eur. J. 2018, 24, 4273-4278. [CrossRef]

227. Aoi, S.; Mase, K.; Ohkubo, K.; Fukuzumi, S. Photocatalytic Reduction of $\mathrm{CO}_{2}$ and $\mathrm{H} 2 \mathrm{O}$ to $\mathrm{CO}$ and $\mathrm{H} 2$ with a Cobalt Chlorin Complex Adsorbed on Multi-Walled Carbon Nanotubes. Catal. Sci. Technol. 2016, 6, 4077-4080. [CrossRef]

228. Ruoff, R.S.; Qian, D.; Liu, W.K. Mechanical Properties of Carbon Nanotubes: Theoretical Predictions and Experimental Measurements. C. R. Phys. 2003, 4, 993-1008. [CrossRef]

229. Salvetat, J.-P.; Bonard, J.-M.; Thomson, N.H.; Kulik, A.J.; Forró, L.; Benoit, W.; Zuppiroli, L. Mechanical Properties of Carbon Nanotubes. Appl. Phys. A 1999, 69, 255-260. [CrossRef]

230. Sharma, S.K.; Gaur, H.; Kulkarni, M.; Patil, G.; Bhattacharya, B.; Sharma, A. PZT-PDMS Composite for Active Damping of Vibrations. Compos. Sci. Technol. 2013, 77, 42-51. [CrossRef]

231. Rujijanagul, G.; Boonyakul, S.; Tunkasiri, T. Effect of the Particle Size of PZT on the Microstructure and the Piezoelectric Properties of 0-3 PZT/Polymer Composites. J. Mater. Sci. Lett. 2001, 20, 1943-1945. [CrossRef]

232. Guan, X.; Zhang, Y.; Li, H.; Ou, J. PZT/PVDF Composites Doped with Carbon Nanotubes. Sens. Actuators A Phys. 2013, $194,228-231$. [CrossRef]

233. Zhang, L.; Cheng, Z.-Y. Development of Polymer-Based 0-3 Composites with High Dielectric Constant. J. Adv. Dielect. 2011, 1, 389-406. [CrossRef]

234. Wang, Z.; Keith Nelson, J.; Hillborg, H.; Zhao, S.; Schadler, L.S. Dielectric Constant and Breakdown Strength of Polymer Composites with High Aspect Ratio Fillers Studied by Finite Element Models. Compos. Sci. Technol. 2013, 76, 29-36. [CrossRef]

235. Kim, H.J.; Kim, Y.J. High Performance Flexible Piezoelectric Pressure Sensor Based on CNTs-Doped 0-3 Ceramic-Epoxy Nanocomposites. Mater. Des. 2018, 151, 133-140. [CrossRef]

236. Han, J.K.; Jeon, D.H.; Cho, S.Y.; Kang, S.W.; Lim, J.; Bu, S.D. Flexible Piezoelectric Generators by Using the Bending Motion Method of Direct-Grown-PZT Nanoparticles on Carbon Nanotubes. Nanomaterials 2017, 7, 308. [CrossRef]

237. Banerjee, S.; Du, W.; Sundar, U.; Cook-Chennault, K.A. Piezoelectric and Dielectric Characterization of MWCNT-Based Nanocomposite Flexible Films. Available online: https://www.hindawi.com/journals/jnm/2018/6939621/ (accessed on 4 February 2021).

238. Gau, C.; Ko, H.S.; Chen, H.T. Piezoresistive Characteristics of MWNT Nanocomposites and Fabrication as a Polymer Pressure Sensor. Nanotechnology 2009, 20, 185503. [CrossRef]

239. Cao, C.L.; Hu, C.G.; Xiong, Y.F.; Han, X.Y.; Xi, Y.; Miao, J. Temperature Dependent Piezoresistive Effect of Multi-Walled Carbon Nanotube Films. Diam. Relat. Mater. 2007, 16, 388-392. [CrossRef]

240. Chen, S.; Luo, J.; Wang, X.; Li, Q.; Zhou, L.; Liu, C.; Feng, C. Fabrication and Piezoresistive/Piezoelectric Sensing Characteristics of Carbon Nanotube/PVA/Nano-ZnO Flexible Composite. Sci. Rep. 2020, 10, 8895. [CrossRef] [PubMed]

241. Li, H.; Zhang, X.; Zhu, Y.; Li, R.; Chen, H.; Gao, P.; Zhang, Y.; Li, T.; Liu, Y.; Li, Q. Hydrothermal Deposition of a Zinc Oxide Nanorod Array on a Carbon Nanotube Film as a Piezoelectric Generator. RSC Adv. 2014, 4, 43772-43777. [CrossRef]

242. Nunes-Pereira, J.; Costa, P.; Lanceros-Mendez, S. 3.9 Piezoelectric Energy Production. In Comprehensive Energy Systems; Dincer, I., Ed.; Elsevier: Oxford, UK, 2018; pp. 380-415. ISBN 978-0-12-814925-6.

243. Hu, Y.; Kang, W.; Fang, Y.; Xie, L.; Qiu, L.; Jin, T. Piezoelectric Poly(Vinylidene Fluoride) (PVDF) Polymer-Based Sensor for Wrist Motion Signal Detection. Appl. Sci. 2018, 8, 836. [CrossRef]

244. Wu, C.-M.; Chou, M.-H.; Zeng, W.-Y. Piezoelectric Response of Aligned Electrospun Polyvinylidene Fluoride/Carbon Nanotube Nanofibrous Membranes. Nanomaterials 2018, 8, 420. [CrossRef] [PubMed]

245. Li, J.; Fang, L.; Sun, B.; Li, X.; Kang, S.H. Review—Recent Progress in Flexible and Stretchable Piezoresistive Sensors and Their Applications. J. Electrochem. Soc. 2020, 167, 037561. [CrossRef]

246. Kim, G.H.; Hong, S.M.; Seo, Y. Piezoelectric Properties of Poly(Vinylidene Fluoride) and Carbon Nanotube Blends: $\beta$-Phase Development. Phys. Chem. Chem. Phys. 2009, 11, 10506-10512. [CrossRef] 
247. Kabir, E.; Khatun, M.; Nasrin, L.; Raihan, M.J.; Rahman, M. Pure $\beta$-Phase Formation in Polyvinylidene Fluoride (PVDF)-Carbon Nanotube Composites. J. Phys. D Appl. Phys. 2017, 50, 163002. [CrossRef]

248. Baughman, R.H.; Cui, C.; Zakhidov, A.A.; Iqbal, Z.; Barisci, J.N.; Spinks, G.M.; Wallace, G.G.; Mazzoldi, A.; Rossi, D.D.; Rinzler, A.G.; et al. Carbon Nanotube Actuators. Science 1999, 284, 1340-1344. [CrossRef]

249. Wang, C.; Wang, Y.; Yao, Y.; Luo, W.; Wan, J.; Dai, J.; Hitz, E.; Fu, K.K.; Hu, L. A Solution-Processed High-Temperature, Flexible, Thin-Film Actuator. Adv. Mater. 2016, 28, 8618-8624. [CrossRef] [PubMed]

250. Amjadi, M.; Sitti, M. Self-Sensing Paper Actuators Based on Graphite-Carbon Nanotube Hybrid Films. Adv. Sci. 2018, 5, 1800239. [CrossRef] [PubMed]

251. Liang, Y.; Xiao, P.; Ni, F.; Zhang, L.; Zhang, T.; Wang, S.; Zhou, W.; Lu, W.; Kuo, S.-W.; Chen, T. Biomimetic Underwater Self-Perceptive Actuating Soft System Based on Highly Compliant, Morphable and Conductive Sandwiched Thin Films. Nano Energy 2021, 81, 105617. [CrossRef] 